\title{
Environmental Flows in the Rocky Mountain West: A Progress Report
}

Lawrence J. MacDonnell

Follow this and additional works at: https://digitalrepository.unm.edu/uc_rio_chama

\section{Recommended Citation}

MacDonnell, Lawrence J.. "Environmental Flows in the Rocky Mountain West: A Progress Report." (2009). https://digitalrepository.unm.edu/uc_rio_chama/19

This Article is brought to you for free and open access by the The Utton Transboundary Resources Center at UNM Digital Repository. It has been accepted for inclusion in Law of the Rio Chama by an authorized administrator of UNM Digital Repository. For more information, please contact amywinter@unm.edu, Isloane@salud.unm.edu, sarahrk@unm.edu. 


\title{
Wyoming LaW REVIEW
}

VOLUME 9

2009

NUMBER 2

\section{ENVIRONMENTAL FLOWS IN THE ROCKY MOUNTAIN WEST: A PROGRESS REPORT}

\author{
Lawrence J. MacDonnell*
}

INTRODUCTION

Westerners are mostly pragmatic about water. That's especially true for people whose families have lived in this region for a long time. They know that, to live in a land with limited rain, the water in creeks and rivers and aquifers has to be put to work. They know that means dams, diversions, and pumps, using water to grow crops and sustain cities. That's what it means to build a good life in arid country.

Westerners also love the places where they live and play. They love their open spaces, their red rock canyons, their snow-covered mountains. Mostly they live in cities and, increasingly, they expect their cities to be attractive and livable. They also love the special places they can get to on the weekends or for vacations. An increasing number are moving to those places. These are often the places that did not get changed much when the region's economy depended heavily on development of its natural resources. In many cases, these are places where there are rivers and streams, springs and marshes_-places with water.

The legal rules governing use of water in this region developed out of the needs of early westerners to put water to direct use and to have certainty that their uses would be protected. ${ }^{1}$ These uses required control of some portion of water, typically involving diversion of water out of a river into a ditch for transport to a place of use and storage of water behind a dam. The rules rewarded the person making the effort to capture and use water with a priority right, superior to anyone who came later-no matter what their need. The rules made it clear

* Special acknowledgement is given to Robert Wigington and Bruce Driver for their thorough review and many useful suggestions for an earlier draft of this article.

1 See generally Robert G. Dunbar, Forging New Rights in Western Waters (1983). 
that only beneficial uses would be protected. They demanded continuation of the use to maintain the right. A no-nonsense, utilitarian approach suited to the time and place.

There was nothing in the rules, however, about water for the river itself. Nothing about how it worked if someone wanted to be sure there was enough water to maintain a valuable fishery, nothing about protecting flows that maintained cottonwoods and willows in riparian areas, nothing about keeping flows to allow people to swim and to boat, nothing about just making sure that rivers didn't totally dry up. For a long time, nobody paid much attention to these considerations.

Today, rivers serve a broader function in the Rocky Mountain West and elsewhere. They are still essential sources of water for agriculture and for cities, but they are also places people go for recreation, for renewal, for enjoyment. People go there for the astonishing amount of life these places support. The region's economy is now as dependent on healthy rivers as it is on diverted water.

This regional shift in how people view rivers has been slow but sure. In a sense, it is revolutionary. It turns upside down 100 years of effort to put every drop of water to some kind of direct human use, in which water undiverted was water wasted, in which success was measured by how much water was beneficially consumed.

Despite this dramatic shift in human perception about the importance of keeping water in rivers and streams, the changes required of the legal system to accommodate this shift have been relatively modest. All that was really necessary was to recognize that environmental uses of water are beneficial and provide rules by which such uses of water can be protected. This is exactly what prior appropriation is all about: encouraging beneficial uses of water by protecting such uses from being impaired by subsequent uses. State water laws have adjusted in varying degrees to acknowledge demand for protection of environmental flows. ${ }^{2}$

2 The literature describing instream flow laws and programs is growing. E.g., LAWRENCE J. MacDonnell, Teresa A. Rice \& Steven J. Shupe, Instream Flow Protection in the West (ed. 1989) and (rev. ed. 1993) (providing an initial summary of laws in the western states). This state-by-state summary was followed by a more topical discussion of instream flow policy. DAVID M. Gillilan \& Thomas C. Brown, Instream Flow Protection: Seeking a Balance in Western Water Use (1997). A series of law review articles followed. E.g., Cynthia F. Covell, A Survey of State Instream Flow Programs in the Western United States, 1 U. of Denver Water L. Rev. 177 (1998); Jesse A. Boyd, Hip Deep: A Survey of State Instream Flow Law from the Rocky Mountains to the Pacific Ocean, 43 NaT. Res. J. 1151 (2003); Charlton H. Bonham, Perspectives from the Field: A Review of Western Instream Flow Issues and Recommendations for a New Water Future, 36 ENVTL. L. 1205 (2006); and Adell Louise Amos, The Use of State Instream Flow Law for Federal Lands: Respecting State Control While Meeting Federal Purposes, 36 EnVTL. L. 1237 (2006). The Colorado Water Conservation Board supported a comprehensive analysis of instream flow programs in 
Yet progress has been uneven. Many in the traditional water community still believe that water in the West is simply too scarce to be permanently committed to environmental or recreational purposes. Such uses, they believe, should be incidental to other, more essential, uses of water-nice if they can be supported but not necessary in the way, say, that water for irrigation is necessary. Yet there are many in these states who believe that places with water are special, that they are an essential part of the state's heritage, to be protected and passed along to future generations. They see healthy rivers as necessary to the economy of the future, just as irrigated agriculture was necessary to the economy of the past. They see environmental flows as a beneficial use of water of equal importance with other, more traditional beneficial uses.

Freshwater ecosystems contain far greater concentrations of life than land or ocean systems. ${ }^{3}$ Human alteration of these freshwater-based systems has resulted in a rate of species extinction five times greater than for land-based species. ${ }^{4}$ The Federal Endangered Species Act ("ESA") represents a national commitment to reverse this trend, presenting a substantial challenge to find ways to integrate human uses of water systems with the needs of dependent species. Global warming, with its accompanying increases in stream water temperatures, increases in evaporation, and alterations of flows adds another layer of complexity to this challenge.

This article surveys legal and programmatic developments in the eight Rocky Mountain states-Arizona, Colorado, Idaho, Montana, Nevada, New Mexico, Utah, and Wyoming_related to commitment of water for environmental purposes (referred to here as "environmental flows"). It is intended to provide an assessment of the manner in which these states have responded to growing public demands for such flows. ${ }^{6}$ Part I briefly discusses the two primary tasks

western states. See generally Sasha Charney, Colo. Water Conservation Bd., Decades Down the Road: An Analysis of Instream Flow Programs in Colorado and the Western United StATES (July 2005). Trout Unlimited commissioned a report focusing on the transactional aspects of shifting existing water uses to environmental flows. Steven Malloch, Trout UnLimited, LiQuid Assets: Protecting and Restoring the West's Rivers and Wetlands through Environmental Water Transactions (2005), available at http://www.tu.org/atf/cf/\%7BED0023C4-EA23-43969371-8509DC5B4953\%7D/Malloch.LiquidAssets.2005.pdf (last visited Feb. 3, 2009). For a discussion of relevant laws in all states as well as the Canadian provinces, see L. MacDonnell, Return to the River: Environmental Flow Policy in the United States and Canada, J. Am. W. Mgt. Ass'N (forthcoming 2009).

${ }^{3}$ Sandra Postel \& Brian Richter, Rivers for Life: Managing Water for People and NATURE 26 (2003).

${ }^{4}$ Id.

516 U.S.C. $\$ \$ 1531-1544$ (2007).

${ }^{6}$ The research for this paper was commissioned by Western Progress, a nonprofit focused on the Rocky Mountain West that closed up shop at the end of 2008. The paper reflects information gathered from nearly 60 interviews with knowledgeable people in each of the states. These people are acknowledged by state in Part III. 
of these laws and programs: protecting some portion of remaining flows and restoring some flows that have been lost. Part II provides a state-by-state look at environmental flow protection and restoration efforts. While there are important developments in all the states, the approaches tend to differ considerably. Part III provides some general observations respecting progress and challenges in these states. Part IV offers some recommendations for next steps on a state-by-state basis. Part $V$ provides some concluding thoughts. The article begins with the basic legal framework.

\section{Part I-The Environmental Flow Protection Framework}

The legal and policy framework can be divided into two parts: elements that serve to keep unappropriated water in streams and rivers and elements that facilitate flow restoration in dewatered streams.

\section{A. Keeping Water in Rivers}

There are now established means under state law in every Rocky Mountain state except New Mexico and Utah to keep unappropriated water instream for environmental benefits. The states have taken different approaches. Four of the states-Colorado, Idaho, Montana, and Wyoming-have enacted special legislation providing specific rules and procedures by which water may be protected instream (referred to as either instream flows or minimum flows)? Court decisions in Arizona and Nevada have determined that environmental flows may be appropriated under existing state water laws. ${ }^{8}$ In New Mexico, there is an opinion of the Attorney General that appropriations for environmental flows may be possible with some kind of diversion structure-an option not yet tested. ${ }^{9}$ Utah law allows changing existing rights to instream flow but does not authorize appropriations for environmental flows. ${ }^{10}$

Water rights for environmental flows are different from traditional appropriations because there is no need for a point of diversion. Stream flows of a specified rate or rates, described in cubic feet per second, are appropriated or

7 Colo. Rev. Stat. \$ 37-92-102 (2008); Idaho Code Ann. \$ 42-1501 (2008); Mont. Code ANN. \$ 85-2-316 (2008); Wyo. STAT. ANN. \$ 41-3-1001(a) (2008).

${ }^{8}$ McClellan v. Jantzen, 547 P.2d 494 (Ariz. Ct. App. 1976); State v. Morros, 766 P.2d 263 (Nev. 1988). The Arizona Department of Water Resources has developed detailed guidance for applicants for instream flows. Ariz. Dep't of Water Res., A Guide to Filing Applications for InSTREAM FLOW WATER Rights In ARIZONA (1991), available at http://www.adwr.state.az.us/dwr/ content/Find_by_Program/Hydrology/Surface_Water_and_Recharge_Section_files/A_Guide_to_ Filing_Applications_for_Instream_Flow_Water_Rights_in_Arizona.pdf (last visited Feb. 3, 2009).

998 Op. Att'y Gen. 01 (1998).

10 Utah Code Ann. $\$ 73-3-3(11)(\mathrm{g})(\mathrm{i})$ (2008). Protection of environmental flows has occurred in other contexts in Utah. See M. Holden, Instream Flows in Utah, in InSTREAM FLow Protection in the West (1989), supra note 2, at 365. 
reserved at a described point or between two points along a stream. For ponds and lakes, unclaimed water is appropriated at some specified elevation level. The absence of a point of diversion has been the subject of litigation in several states, with the courts uniformly agreeing that a valid instream flow appropriation under state water law does not require a point of diversion. ${ }^{11}$

Approaches vary among the Rocky Mountain states in a number of respects. Most states limit who may establish an environmental flow right, typically restricting holders to a designated state agency. States vary in the purposes for which environmental flow rights may be established, with maintenance of a fishery the most common. As with any appropriation, the instream applicant is limited to that amount of water reasonably necessary to accomplish the purpose of the appropriation. Each state follows somewhat different procedures for quantifying the claimed flows. ${ }^{12}$ In all cases, the claims are necessarily limited to unappropriated water. Typically the applicant must demonstrate the availability of the water it seeks to appropriate for instream flows.

Environmental flow rights hold the priority of the date of appropriation, commonly the date the application is filed with the state, in the same manner as other appropriations. Given the very recent vintage of such rights, they are typically very junior. Nevertheless, they are protected against flow reductions caused by later appropriations and may require such appropriations to cease if the protected environmental flow is being reduced because of the later use. Moreover, as water rights, environmental flows are protected from injury in the case of a change of a water right in the same source of water, just as any other water right. In general, environmental flow appropriations have the same permanency as any other water right.

States with legislated programs generally have focused on protecting stream segments with high sport fishery values. Typically, these are segments near headwaters or otherwise in remote areas with limited competition for the water. In many cases, the segments are on public lands in which additional water development would be subject to federal review and control or otherwise on segments with public access for fishing. The segment is then evaluated using one of the many methodologies available for linking flows to fishery needs so that the quantity sought to be appropriated can be objectively represented. ${ }^{13}$ The

11 See, e.g., Idaho Dep't of Parks v. Idaho Dep't of Water Admin., 530 P.2d 924 (Idaho 1974); In re Application A-16642, 463 N.W. 2d 591 (Neb. 1990); In re Adjudication of the Mo. River Drainage Area, 55 P.2d 396 (Mont. 2002); Phelps Dodge Corp. v. Ariz. Dep't of Water Res., 118 P.3d 1110 (Ariz. Ct. App. 2005).

12 See Charney, supra note 2 (providing a summary of approaches in each western state).

13 Originally, it was common for flows to be established at a single rate year round-often representing the minimum flow regarded as necessary to simply maintain an existing sport fishery. instream Flow Council, Instream Flows for Riverine Resource Stewardship 5-6 (rev. ed. 
application still must go through the ordinary water permitting decision-making process to provide an opportunity for review by water rights holders and other interested parties. The permit is held in the name of the state. The designated state agency then is charged with monitoring stream conditions to protect the appropriation. A similar process is followed in the states recognizing environmental flow appropriations within their traditional water permitting processes.

\section{B. Putting Water Back in Rivers}

As opportunities for setting aside unclaimed water diminish, attention has turned to restoring stream flows and other habitat conditions in heavily appropriated rivers. Much of this effort involves changing the use of existing water rights, either permanently or temporarily, so that water previously diverted for use can stay instream. The positives are clear: improving — not just maintaining-existing stream flows; flows protected with the seniority of the original appropriation; and targeted improvements in the places of greatest need. The challenges are many, however: the limited number of water rights available for acquisition; the cost of acquisition, especially compared to the funds available; and the time and effort necessary to go through the change-of-use process.

In response to growing interest in environmental flow transactions, ${ }^{14}$ some states are modifying their laws to facilitate these efforts. Thus, statutes in three of the region's states now explicitly recognize that existing water rights may be changed to environmental flow purposes. ${ }^{15}$ In addition, there has been some movement toward allowing parties other than the state to change an existing right to environmental flow purposes. ${ }^{16}$

Temporary arrangements that allow historically diverted water to remain instream are becoming more common. ${ }^{17}$ Several states specifically authorize temporary changes of water rights, subject to the same review as required for permanent changes. ${ }^{18}$ In addition, several states have established specific programs

2004). Methodologies for evaluating flow conditions necessary to adequately protect fisheries and other aquatic and riparian resources have evolved greatly in recent years. Id. at $98 \mathrm{et} \mathrm{seq.} \mathrm{It} \mathrm{remains}$ uncommon to have an appropriation that varies across the year mirroring the natural variability of the hydrologic system.

${ }^{14}$ An excellent overview of environmental water transactions is provided in Malloch, supra note 2 .

15 Colo. Rev. Stat. $\$ 37-92-102$ (3); Mont. Code Ann. $\$ \$ 85-2-320$, 402, 408, 420, 436; UtAH Code Ann. \$ 73-3-3 (11)(g)(i). As mentioned, Utah only allows instream flow protection based on changing an existing water right, not by appropriation or reservation.

16 Ariz. Rev. Stat. $\$ 45-172$ (A).

${ }_{17}$ Malloch, supra note 2, at 20.

${ }^{18}$ Idaho Code Ann. $\$ 42-222 A$; Mont. Code Ann. $\$ 85-2-108$; Nev. Rev. Stat. $\$ 533.345$; N.M. Stat. Ann. \$72-12-7; Utah Code Ann. \$73-3-3. 
by which water rights may be leased for environmental flow purposes. ${ }^{19}$ Idaho has utilized water banks to facilitate transactions involving temporarily changing existing rights to other uses, including instream flows. ${ }^{20}$ Such programs have been attractive to water right holders not interested in permanently giving up their rights. Some temporary arrangements are tailored to reduce diversions during particular periods of the irrigation season when environmental flows are especially important; others operate only during drought years. An advantage of non-divert agreements is they don't need to go through the state change of use review process. Flows can only be protected instream, however, until the next headgate.

The next section takes a more detailed look at the legal framework and its utilization for environmental flows in each of the region's eight states.

\section{Part II-State Summaries}

\section{A. Arizona $^{21}$}

\section{Introduction}

Aside from the Colorado River, there are few perennial streams in Arizona. Generally these are headwaters and tributaries to the larger streams, or they are segments located below storage reservoirs. Arizona has more freshwater species at risk of extinction than any other state. ${ }^{22}$ Of the 35 native freshwater species

${ }^{19}$ Colo. Rev. Stat. \$\$ 37-80.5-104.5; \$ 37-92-102 (3); \$ 37-92-305(b); Mont. Code Ann. \$\$ 85-2-113, -407. Montana pioneered development of a leasing program, beginning with limited authorization only to its Department of Fish, Wildlife, and Parks and then extending that authority to any party. Trout Unlimited, Private Water Leasing: A Montana Approach (Undated) available at http://www.tu.org/atf/cf/\%7B0D18ECB7-7347-445B-A38E-65B282BBBD8A\%7D/MT_Water Report.pdf (last visited Feb. 3, 2009). Colorado has allowed the Colorado Water Conservation Board to accept donations or make acquisitions of water rights for change to instream flows since 1986. Covell, supra note 2, at 185. In 2008, the General Assembly expanded and clarified the CWCB's leasing authority. Colo. Rev. Stat. \$ 37-92-102 (3).

${ }^{20}$ Malloch, supra note 2, at 60. Under special legislative authority, the Bureau of Reclamation utilizes the Upper Snake bank to rent water in storage for downstream release to help meet the flow need of salmon. Idaho Code AnN. $\$ 42-1763$ B. The legislature established a special bank in the Lemhi River Basin to facilitate transfers of irrigation water to instream flows to enable salmon to reach upstream spawning habitat in the watershed. IDAHO CODE ANN. $\$ \$ 42-1506 ; 1765 \mathrm{~A}$. A state bank, operated by the Idaho Water Resources Department, enables temporary transfers of natural flow water rights to other uses including instream flow. IDAHO CODE ANN. \$ 42-1762 (2).

${ }^{21}$ Assistance for this section was provided by Jean Calhoun, Arizona Nature Conservancy; Randy Bramer, Office of General Counsel, U.S. Department of Agriculture, Colorado; Dave Weedman, Arizona Game and Fish Department; Tom Colozzo, Arizona Nature Conservancy; Sharon Megdahl, Water Resources Research Center, University of Arizona; Kathy Nelson, Tonto National Forest, Arizona; and Andrew Hautzinger, USFWS, New Mexico.

22 Bruce A. Stein, States of the Union: Ranking America's Biodiversity, NatureServe (2002). 
found in Arizona, 21 are federally listed under the Endangered Species Act. ${ }^{23}$ Riparian vegetation with its unusually rich biodiversity is also at risk. A recent study has identified state heritage waters, regarded as particularly important for protection..$^{24}$

Arizona does not have a state program directed at protection of environmental flows. Arizona courts have found that water may be appropriated for recreation and wildlife purposes under Arizona law, ${ }^{25}$ and the State Department of Water Resources has developed guidance for those interested in filing for instream flow water rights. ${ }^{26}$ The Arizona legislature has established financial support for river restoration actions that includes funding that can be used for acquisition of Central Arizona Project water or effluent water. ${ }^{27}$ We look first at streamflow protection actions under Arizona law and then at some examples involving stream restoration and protection efforts.

\section{Instream Flow Protection under State Law}

In 1979, The Nature Conservancy ("TNC") filed the first application seeking instream flow rights in Arizona. TNC sought rights in Ramsey Creek along which it owned property. The Arizona Department of Water Resources ("ADWR") used this application as a test case out of which it developed substantial guidelines for instream flow applicants. ${ }^{28}$ Subsequently, TNC obtained permits for rights associated with properties along Aravaipa Creek, O'Donnell Creek, the Hassayampa River, Bass Canyon, Hot Springs Canyon, and Buehman Creek.

As of the end of 2007, 100 applications for instream flows had been filed with ADWR; 33 permits have been issued. ${ }^{29}$ The Bureau of Land Management has filed 31 applications; seven have been permitted. The Forest Service has filed 41 applications; 10 have been permitted.

Litigation, decided in 2005, tested the legality of instream flow permits under Arizona law. Phelps Dodge challenged Forest Service applications for flows in a segment of Cherry Creek, a tributary of the Salt River, as it passes through the

${ }^{23}$ Dale S. Turner \& Michael D. List, Habitat Mapping and Conservation Analysis to Identify Critical Streams for Arizona's Native Fish, 17 Aquatic Conservation: Marine and Freshwater ECOSYSTEMS 737-48 (2007).

${ }^{24}$ Lawrence E. Stevens \& Patricia West, Arizona Water Institute, Arizona Heritage WATERS (2008).

${ }^{25}$ McClellan v. Jantzen, 547 P.2d 494 (Ariz. Ct. App. 1976).

${ }^{26}$ Ariz. Dep'T of Water Res., supra note 8.

${ }^{27}$ Ariz. Rev. Stat. Ann. \$ 45-2113.

${ }^{28}$ See Ariz. Dep't of Water Res., supra note 8.

${ }^{29}$ Print-out provided by Ariz. Dep't of Water Res. in response to Public Records Request, received May 21, 2008 (on file with author). 
Tonto National Forest. In particular, Phelps Dodge asserted that, under Arizona water law, an appropriation of water required a physical diversion. In Phelps Dodge Corp. v. Arizona Dep't of Water Resources, ${ }^{30}$ the Arizona Court of Appeals found that a physical diversion was not a requirement and upheld the ADWR permit program.

Arizona statutes provide that water rights may be severed from the land on which they have historically been used and transferred to a new use. ${ }^{31}$ It limits such transfers to the state or its political subdivisions if the new use is for recreation or wildlife purposes. Thus non-state owners of water rights cannot change the use to environmental flows. Several transfer applications that would sever water rights and change their use to environmental flows are currently pending while the Arizona Department of Water Resources establishes guidance for their review. ${ }^{32}$

Ground water supplies a large portion of water uses in the state. ${ }^{33}$ Long-term pumping from aquifers has mined the water supply, dropping the water table in many places to below its point of contact with rivers and streams. Under Arizona law, ground water is regulated separately from surface water. Only since 2000, in the context of the adjudication of surface water rights in the Gila River Basin, has state law recognized the physical linkage between aquifers and streams. ${ }^{34}$ Consequently, groundwater pumping remains one of the greatest challenges to protecting water for environmental benefits in Arizona.

\section{Examples of Flow Restoration and Protection Efforts}

According to The Nature Conservancy, Arizona rivers have lost 35\% of their natural perennial flows. ${ }^{35}$ On the big, historically perennial rivers- the Colorado, Gila, Salt, and Verde- $91 \%$ of the miles with flowing water have been lost. Attention has focused on protecting remaining segments with perennial flows and restoring flows on other segments where possible.

30118 P.3d 1110 (Ariz. Ct. App. 2005).

${ }^{31}$ Ariz. Rev. Stat. Ann. \$ 45-172.

${ }^{32}$ The unadjudicated status of these rights means that their validity is still subject to challenge. Cessation of diversion as an instream flow right could be challenged as a forfeiture of the right. Personal Communication with Robert Wigington, Counsel and Manager for the Global Freshwater Team (July 14, 2008).

${ }^{33}$ Arizona does not keep track of the extent of groundwater pumping in the state.

${ }^{34}$ In re Gen. Adjudication of All Rights to Use Water in Gila River Sys. \& Source, 9 P.3d 1069 (Ariz. 2000).

${ }^{35}$ Arizona Conservation Science, Projects, Arizona Rivers and Water, http://azconservation. org/ (last visited April 3, 2009). 


\section{a. The San Pedro}

The San Pedro flows north out of Mexico into the United States. Remarkably, more than 350 species of birds use the habitat in this watershed. ${ }^{36}$ Because of the unique biodiversity in the watershed, TNC has made a sustained effort to support its protection. Rapid growth in the watershed based on ground water threatens the river's limited surface flows. Congress established the San Pedro Riparian National Conservation Area in 1988, managed by the Bureau of Land Management, with the objective of protecting the areas unique desert riparian system. ${ }^{37}$ In 1998, the various federal, state, local, and non-governmental organization ("NGO") entities working in the watershed formed the Upper San Pedro Partnership. ${ }^{38}$ The initial focus was to retire irrigated agriculture on lands adjacent to the river and end the associated groundwater pumping. In 2003, Congress furthered the federal commitment to find solutions for the multiple water needs in the area. ${ }^{39}$ The Partnership has established a goal of sustainable yield of the area's groundwater aquifer, an objective that may require supplementing the area's normally available water resources.

\section{b. The Upper and Middle Verde}

The Verde River is one of Arizona's few remaining perennial streams and includes Arizona's only Wild and Scenic River. ${ }^{40}$ It originates as discharge from groundwater aquifers and flows generally south to its confluence with the Salt River. While there are diversions for irrigated agriculture in the watershed, most of the water is committed to downstream users outside the Verde-primarily for the Salt River Project. Population in and adjacent to the watershed, especially in the headwaters, has grown dramatically since the 1980s. The groundwater pumping associated with supplying this population has begun to measurably affect surface flows in the Verde. In response, a broad range of interests are now working on finding ways to better manage the watershed's water supplies. In 2007, The Nature Conservancy sponsored a workshop and proceedings that helped establish the scientific basis for addressing the hydrologic-ecologic relationships. ${ }^{41}$

36 The Nature Conservancy, San Pedro River, Arizona, http://www.nature.org/initiatives/fresh water/work/sanpedroriver.html (last visited April 3, 2009).

${ }^{37}$ Bureau of Land Management, San Pedro Riparian NCA, http://www.blm.gov/az/st/en/ prog/blm_special_areas/ncarea/sprnca.html (last visited April 3, 2009).

38 See generally Upper San Pedro Partnership, www.usppartnership.com.

${ }^{39}$ Defense Authorization Act of 2004, Pub. L. No. 108-136, \$321 (2004).

${ }^{40}$ See National Wild and Scenic Rivers, Verde River, http://www.rivers.gov/wildriverslist. html (last visited April 3, 2009).

41 Jeanmarie A. Haney et al., Ecologic Implications of Verde River Flows (2008), available at http://azconservation.org/dl/TNCAZ_VerdeRiver_Ecological_Flows.pdf (last visited April 6, 2009). 
In 2005, Congress provided funding to a Verde River Basin Partnership for water planning and scientific studies, including a U.S. Geological study to develop a water budget. ${ }^{42}$

\section{c. The Bill Williams}

As part of the Sustainable Rivers Project, The Nature Conservancy is working with the U.S. Army Corps of Engineers ("Corps") to help develop operating regimes at several Corps dams around the United States to produce beneficial environmental flows. ${ }^{43}$ Alamo Dam on the Bill Williams River in Arizona is one of the projects. The Bill Williams River is located in west-central Arizona in a relatively remote area with little human population. It flows west into the Colorado River at Lake Havasu. The Corps constructed Alamo Dam in 1968 for flood control purposes. ${ }^{44}$

The first step in the process was to define a set of flow requirements for sustaining the long-term ecological health of the Bill Williams River corridor, with the overall goal of maximizing native biodiversity within the flood plain. ${ }^{45}$ The major effect of the Alamo Dam on the river has been to substantially reduce peak flows, reduce the variability of average flows, and eliminate the sediment transported from above. The result was an increase in the riparian vegetation in the floodplain and a narrowing and incising of the stream channel. The Corps is now experimenting with flow releases to test the expected biotic responses.

\section{Summary}

Human demands for water in Arizona have greatly altered the hydrologic systems. Interest has grown in protecting the few remaining streams with perennial flows and other special places with water. Access to water from the Colorado River through the Central Arizona Project is enabling some users to reduce their reliance on ground water, and the state is attempting to move toward balancing withdrawals with recharge in five management areas with the most concentrated use. The state has no program for protecting or restoring water for environmental purposes, but its existing laws have been interpreted to allow parties to appropriate

${ }^{42}$ Northern Arizona Land Exchange \& Verde River Basin Partnership Act of 2005, Pub. L. No. 109-110, \$\$ 201 et seq.

43 The Nature Conservancy, The Sustainable Rivers Project, http://www.nature.org/ initiatives/freshwater/partnership/ (last visited April 3, 2009).

${ }^{44}$ The Bill Williams River Corridor Steering Committee, The Physical Setting, http://bill williamsriver.org/Setting/ (last visited April 3, 2009) ("Alamo Dam was constructed by the Corps of Engineers as a multipurpose project under authorization of the Flood Control Act of December 22, 1944 (Public Law 534, 78th Congress, 2nd Session).”).

45 Patrick B. Shafroth \& Vanessa B. Beauchamp, U.S. Geological Survey, Defining Ecosystem Flow Requirements for the Bill Williams River, Arizona 135 (2006), available at http://www.fort.usgs.gov/products/publications/21745/21745.pdf (last visited April 6, 2009). 
unappropriated water for these purposes. Permits for such appropriations have been granted, and others are pending. In addition, there are several significant, multi-party processes underway working on protection of important rivers. As further discussed in Part IV below, Arizona could take fuller advantage of the considerable interest in the state in environmental flows by establishing a state program for stream protection and restoration and allowing non-state parties to lease or purchase existing water rights for this purpose.

\section{B. Colorado $^{46}$}

\section{Introduction}

Colorado sits at the heart of the Rocky Mountain West, with the highest average elevation of any state. ${ }^{47} \mathrm{It}$ is a headwaters state, the source of major rivers including the Platte, the Arkansas, the Rio Grande, and the Colorado. Statewide, annual average precipitation is 17 inches-semiarid on the eastern plains but much wetter in the mountainous areas. ${ }^{48}$ Its growing population, now totaling about 4.8 million people, is heavily concentrated along the Front Range on the east side of the Rockies, but population on the state's western slope is increasing. ${ }^{49}$ Average annual runoff is estimated to be about 16 million acre-feet. ${ }^{50}$ Water withdrawals for all uses totaled about 12.6 million acre-feet in 2000, 11.4 for irrigated agriculture. $^{51}$

The Colorado General Assembly put in place a state instream flow program in $1973 .^{52}$ Increased attention now is focusing on restoring flows in valuable segments historically dewatered by diversions, sometimes motivated in part by the need to protect species listed for protection under the Federal Endangered Species Act. Our discussion begins with a look at the state instream flow program.

${ }^{46}$ Assistance for this section was provided by Linda Bassi, Colorado Water Conservation Board; Mark Uppendahl, Colorado Division of Wildlife; Melinda Kassen and Drew Peternell, Trout Unlimited, Colorado; Randy Bramer and Lois Witte, Office of General Counsel, U.S. Department of Agriculture, Colorado; and Mike Browning, Colorado Water Trust.

${ }^{47}$ NetState, The Geography of Colorado, http://www.netstate.com/states/geography/co_ geography.htm (last visited April 3, 2009).

${ }_{48}$ Precipitation in Colorado, http://waterknowledge.colostate.edu/precip.htm (last visited April 3, 2009).

49 See U.S. Census Bureau, State \& County QuickFacts, http://quickfacts.census.gov/qfd/ states/08000.html (last visited April 3, 2009).

${ }^{50}$ Personal Communication with Kelly DiNatale, Principal and Senior Water Resources Engineer, CDM, Inc. (June 11, 2008). The communication was based on STATEWIDE Water SupPLY Initiative, Colo. Water Conservation BD. (2004), available at http://cwcb.state.co.us/IWMD/ SWSITechnicalResources/SWSIPhaseIReport/ (last visited April 6, 2009).

${ }^{51}$ USGS, Estimated Use of Water in the United States for 2000, Table 2, http://pubs.usgs. gov/circ/2004/circ1268/htdocs/table02.html (last visited April 3, 2009).

52 Colo. Rev. Stat. \$37-92-102 (3). 


\section{Instream Flow Appropriations}

Colorado law authorizes a state agency, the Colorado Water Conservation Board, to appropriate unappropriated water to "preserve the natural environment to a reasonable degree." ${ }^{33}$ Under that program, the State has now appropriated water for the natural environment on nearly 1,500 stream segments covering about 8,500 miles of stream, and has also protected the levels of 476 lakes. ${ }^{54}$ Nearly 2,000 decrees for instream flow or lake level protection have been issued through 2006. ${ }^{55}$ Instream flow rights are heavily concentrated in the higher elevation headwaters streams and lakes. ${ }^{56}$ Protection of cold water fisheries has been the dominant purpose. More recently, flows have been appropriated in some lower elevation streams to protect native warm water fisheries, including endangered species of fish in the Colorado and the Yampa rivers. Appropriations have been made to protect other unique natural values, including glacial ponds for salamanders and habitat for waterfowl..$^{57}$

The Colorado Division of Wildlife ("DOW") plays an important role in identifying places where there are important fisheries that warrant protection. ${ }^{58}$ This agency then uses a particular methodology for quantifying that portion of the remaining flows it believes should be protected to maintain the fishery. DOW then provides a report with this information to the Colorado Water Conservation Board ("CWCB"), the agency authorized to file for an instream flow right. CWCB staff evaluates existing stream hydrology to verify that the desired flows are in fact available and weighs the instream use against other potential future uses of the water. The staff may make some modifications to the DOW proposal before submitting the information to the Board, composed primarily of members from around the state appointed by the governor. Upon board approval, the agency then files an application with the water court for the basin in which the appropriation is made. Other holders of water rights may file objections, typically based on concerns about potential adverse effects on their rights. Assuming objections are resolved and the legal requirements met, the court awards a decree for the right.

53 Id. No other entity or individual is permitted to appropriate water for environmental flows.

${ }^{54}$ Colo. Water Conservation Bd., New Appropriations, http://cwcb.state.co.us/StreamAnd Lake/ NewAppropriations/ (last visited April 3, 2009).

55 See Colo. Water Conservation Bd., Tools \& Resources, http://cwcb.state.co.us/Stream AndLake/RelatedInformation/ToolsResources/tools.htm (last visited April 3, 2009).

56 See Streams Included in Colorado's Instream Flow Program, http://cwcb.state.co.us/NR/ rdonlyres/4EFEF72D-8017-42ED-A555-66D1A5B7C8CB/0/StatewideISFMap.jpg (last visited Feb. 2, 2009) (providing a map showing the locations of instream appropriations).

57 Dan Merriman \& Anne M. Janicki, Colo. Water Conservation Bd., Colorado's Instream Flow Program-How It Works and Why It's Good for Colorado (n.d.), available at http://cwcb.state.co.us/NR/rdonlyres/6333F3FC-E2F8-4E7E-9BD3690FCC4285D1/0/Final RiparianAssocPaper.pdf (last visited April 6, 2009).

58 Id. at 2. 
The CWCB has developed an active monitoring program for its rights on many streams and has begun placing "calls" on more junior appropriators when flows drop below appropriated levels. ${ }^{59}$ In addition, staff reviews all applications for new or changed rights for potential injury to instream flow rights. ${ }^{60}$

In general, Colorado has taken a cautious approach to appropriating water for instream flows. Its methodology for determining flows is considered by some to be conservative, sufficient to ensure the maintenance of essential fish habitat but not to provide for other ecological values. ${ }^{61}$ Originally, the State obtained a single year-round flow but now typically appropriates two or more flow rates to reflect some seasonal variations in stream flows.

Instream flow appropriations limit the ability to make subsequent upstream appropriations of water from the source. Thus, when a year-round instream flow appropriation of 12 cubic feet per second ("cfs") on Snowmass Creek prevented wintertime diversions of water for snowmaking at a nearby ski area, the CWCB reevaluated its decree and determined that protection of the stream's natural environment to a reasonable degree only required three cfs during the winter months. It thus decided not to enforce its rights against proposed new appropriations that would not reduce the flows below three cfs. Aspen Wilderness Workshop brought suit. ${ }^{62}$

The Colorado Supreme Court noted the original decree reflected a determination that the appropriation was the "minimum" necessary to protect the natural environment. ${ }^{63}$ While subsequent information may have changed that determination, the CWCB would need to go through a water court process to change the decree. The Court determined that the CWCB holds the right to instream flow appropriations on behalf of the public: "The Conservation Board has a unique statutory fiduciary duty to protect the public in its administration of its water rights decreed to preserve the natural environment." ${ }^{\prime 4}$ The General Assembly thereafter affirmed the authority of the CWCB to reduce an existing appropriation, but subject to extensive public review and including a water court proceeding. ${ }^{65}$

59 Colo. Water Conservation Bd., Physical Protection, http://cwcb.state.co.us/StreamAnd Lake/Physical/ (last visited April 3, 2009).

${ }^{60}$ Colo. Water Conservation Bd., Legal Protection, http://cwcb.state.co.us/StreamAndLake/ Legal/ (last visited April 3, 2009).

${ }^{61}$ Personal Communication with Drew Peternell, Director of the Colo. Water Project, Trout Unlimited (June 23, 2008). 1995).

${ }^{62}$ Aspen Wilderness Workshop v. Colo. Water Conservation Bd., 901 P.2d 1251 (Colo.

${ }^{63} \mathrm{Id}$. at 1257.

${ }^{64}$ Id. at 1260.

${ }^{65}$ Colo. Rev. Stat. $\$ 37-92-102(4)(b)$. 
The existence of instream flow rights also becomes important if a party seeks to change the place of use of a water right or exchange water from below to above the protected segment. A 2005 Colorado Supreme Court decision provides an example. ${ }^{66}$ In this case, the mountain town of Central City sought to shift water from downstream irrigation use to its municipal water system. It also sought the ability to divert water for municipal use out-of-priority by replacing its depletions under a plan for augmentation. ${ }^{67}$ On an intervening segment of the stream, the State holds a $1.5 \mathrm{cfs}$ instream flow right with a 1987 priority date. The State filed a statement of opposition to protect its right, arguing that its appropriation would be injured by such out-of-priority diversions. Central City responded that it would be diverting under priorities senior to the instream flow appropriation and thus did not have to limit its diversions. Its replacement water sources were located downstream of the instream flow appropriation.

The Colorado Supreme Court noted the statute governing court reviews of applications for plans for augmentation requires a determination that implementation of the plan will not injure vested rights. ${ }^{68} \mathrm{~A}$ decreed instream flow appropriation is a vested right. In the Court's view, the clear legislative intent of establishing instream appropriations was to ensure that flows determined necessary to preserve the natural environment would not be further depleted, at least not without conditions to protect against injury:

The legislature . . clearly envisioned that the instream flow program would obtain, in reasonable measure, its goal of preserving the environment by ensuring that certain stream reaches would not be further depleted without conditions to protect against injury. See $\$ 37-92-102$ (3), C.R.S. (2005). We conclude the legislature instead envisioned the primary value of an instream flow right to derive from a basic tenet of water law: its ability to preserve the stream conditions existing at the time of its appropriation. ${ }^{69}$

The CWCB has adopted an "injury with mitigation" rule under which the board may decide not to oppose a change if there are no other reasonable alternatives and if other beneficial measures are taken. ${ }^{70}$

${ }^{66}$ Colo. Water Conservation Bd. v. City of Central, 125 P.3d 424 (Colo. 2005).

${ }^{67}$ Colo. Rev. Stat. $\$ 37-92-103$ (9). For a discussion of state laws enabling out-of-priority diversions, including Colorado, see Lawrence J. MacDonnell, Out of Priority Water Use: Adding Flexibility to the Prior Appropriation System, 83 Neb. L. Rev. 485 (2004).

${ }^{68}$ Colo. Rev. Stat. $\$ 37-92-305$ (3).

${ }^{69}$ Colo. Water Conservation Bd., 125 P.3d at 439.

${ }^{70} 2$ Colo. Code Regs. $\$$ 8(i)(3). 


\section{Restoring Flows in Dewatered Streams}

As the process of appropriation of flows winds down, attention has turned to places in which there is interest in enhancing flows. The CWCB has long had the authority to acquire existing rights for instream flows by donation, purchase, lease, or contract, but its use has been relatively modest. Indeed, until 2001 the statutory language suggested the CWCB could only preserve, not restore or enhance, the existing natural environment. That year, however, the General Assembly specifically broadened the CWCB's role to include improvement of the stream environment. ${ }^{71}$ Subsequently, the General Assembly authorized the CWCB to receive temporary loans of agricultural water rights, a provision intended to create a mechanism for responding to droughts or other relatively short-term needs. ${ }^{72}$ In 2008, the General Assembly clarified provisions relating to water rights leased, loaned, or contracted to the CWCB to protect against the abandonment of the established consumptive use portion of water during the time the right is used for instream flows and to allow the consumptive use portion to be available for downstream diversion and use. ${ }^{73}$ Any change of use, except the temporary loan of agricultural water, must go through the full water court process. In 2008, the General Assembly for the first time authorized funding under which the CWCB may purchase or lease water rights for instream flows. ${ }^{74}$ As of the end of 2006, the CWCB had received 16 permanent donations and entered into five leases and one intergovernmental agreement shifting water to instream flow uses. ${ }^{75}$ The Colorado Water Trust and Trout Unlimited also are working to obtain water rights that they can donate to the CWCB for instream flows.

${ }^{71}$ Colo. Rev. Stat. \$37-92-102 (3).

72 Colo. Rev. Stat. $\$ 37-83-105$ (2). Such loans are not required to go through a water court change-of-use proceeding.

${ }^{73}$ Colo. Rev. Stat. $\$ 37-92-102$ (3) (revised by H.B. 08-1280, 66th Gen. Assem., 2d Reg. Sess. (Colo. 2008)) ("All Contracts or agreements for water, water rights, or interests in water under this subsection (3) shall provide that, pursuant to the water court decree implementing the contract or agreement, the Board or lessor, lendor, or donor of the water may bring about beneficial use of the historical consumptive use of the leased, loaned, or donated water right downstream of the instream flow reach as fully consumable reusable water."). The revision makes clear the decreed historical consumptive use will not be reduced because of the temporary instream flow use of the right. See id.

${ }^{74}$ H.B. 08-1346, 66th Gen. Assem., 2d Reg. Sess. (Colo. 2008) (enacted as Colo. Rev. Stat. $\$ 37-60-123.7)$.

${ }^{75}$ Colo. Water Conservation Bd., Completed Transactions, http://cwcb.state.co.us/Stream AndLake/WaterAcquisitions/CompletedTransactions/ (last visited April 3, 2009). 


\section{Flows on Federal Lands}

About 35\% of Colorado lands are federally managed, including national forests covering most of the state's high elevation areas. ${ }^{76}$ Most surface flows originate in these high mountain watersheds. Many of the state's appropriations for instream flows are located on stream segments within national forests and on Bureau of Land Management ("BLM") lands. Through negotiation, Colorado has encouraged federal agencies to use the state's water rights system to achieve federal objectives. ${ }^{77}$ Thus, Forest Service claims for water on 303 stream segments within the Rio Grande and Uncompahgre National Forests were resolved by an agreement under which the Forest Service was given state water rights for instream flows to about $85 \%$ of the water in return for waiving its special use and right of way permitting authority to regulate other water diversions. ${ }^{78}$ In 2004 , the State entered into separate memoranda of understanding with the Forest Service and the BLM agreeing to work together to find acceptable approaches to meeting state and federal interests related to water on these federal lands. ${ }^{79}$ The Forest Service sponsored an extensive dialogue among interests, called the Pathfinder process, to seek agreement about preferred strategies for streamflow protection in the Grand Mesa, Uncompahgre, and Gunnison National Forests. ${ }^{80}$ The State and the Federal government worked out an unusual agreement for establishing a federal right for water for the Great Sand Dunes National Park by which the United States holds what is essentially an instream flow right under state water law. ${ }^{81}$

Colorado has only one congressionally-designated Wild and Scenic River: a segment of the Cache la Poudre River from its headwaters downstream about 70 miles. ${ }^{82}$ As part of its land management planning process, the Colorado BLM has

76 Carol Hardy Vincent et al., CRS Report for Congress, Federal Land Management Agencies: Background on Land and Resources Management 3 (2004), available at http:// www.nationalaglawcenter.org/assets/crs/RL32393.pdf (last visited April 3, 2009) [hereinafter Congressional Research Service].

77 By statute, the board is to request recommendations from the U.S. Department of Agriculture and the U.S. Department of the Interior. Colo. Rev. STAT. \$37-92-102 (3).

${ }^{78}$ Interview with Randy Bramer, Office of General Counsel, U.S. Department of Agriculture (June 5, 2008).

79 Memorandum of Understanding between the State of Colo. Dep't of Natural Res. and U.S. Dep't of Agric. Forest Serv. (April 16, 2004); Memorandum of Understanding Between the State of Colo. Dep't of Natural Res. and the Colo. Water Conservation Bd. and U.S. Dep't of the Interior Bureau of Land Mgmt. (September 14, 2005), both available at http://cwcb.state.co.us/ StreamAndLake/RelatedInformation/HotTopics/AgreementsWithFederalAgencies/agreements. htm (last visited April 3, 2009).

${ }^{80}$ See generally Pathfinder Project, http://www.gmugpathfinder.org/ (last visited April 3, 2009) (providing more information about this project).

${ }^{81}$ John D. Leshy, Water Rights for New Federal Land Conservation Programs: A Turn-of-theCentury, 4 U. Den. Water LaW J. 271, 286 (2001).

${ }^{82}$ See National Wild and Scenic Rivers, Cache la Poudre River, http://www.rivers.gov/wsrcache-la-poudre.html (last visited April 3, 2009). 
identified several streams suitable for wild and scenic designation. ${ }^{83}$ The state has been facilitating stakeholder discussions to seek alternatives to formal designation that would still provide protection for these segments, including their flows.

Federal reserved water rights have also been the basis of flow protection in Colorado. Essentially all the flows in streams located in Rocky Mountain National Park, for example, are controlled by the United States under adjudicated state water rights. ${ }^{84}$ Flows of the Gunnison River reserved for the Black Canyon National Monument have just been negotiated and will provide for a year-round base flow of $300 \mathrm{cfs}$ with a 1933 priority date; an annual one-day peak related to inflow (and tied to releases for endangered fish needs); shoulder flows (elevated base flow using a formula in the decree) for 85 days in all but the driest two-year categories; drought-year storage recovery provisions; and subordination to all existing and future in-basin uses up to a total of 60,000 acre-feet. ${ }^{85}$

\section{Flows for Endangered Species}

As an outcome of years of lengthy negotiations among an array of interests, including the state, the U.S. Fish and Wildlife Service has developed a recovery plan for four species of endangered fish with critical habitat in the upper Colorado River. ${ }^{86}$ One aspect of this plan concerns protection and enhancement of flows in a critical stretch of the river near Grand Junction known as the 15 Mile Reach. While a state instream flow appropriation protects base flows in this reach, additional flow targets are satisfied by managed flow releases from several upstream Bureau of Reclamation storage facilities and from dams managed by

${ }^{83}$ Bureau of Land Management, Final Wild and Scenic River Eligibility Report for Kremmling and Glenwood Springs Field Offices, Colorado (2007), available at http://www.blm. gov/rmp/co/kfo-gsfo/documents/FinalEligibilityReport_Mar2007.pdf (last visited April 6, 2009). See also Bureau of Land Management, Grand Junction Field Office, "Wild and Scenic River Eligibility Report," March 24, 2009, available at http://www.blm.gov/pgdata/etc/medialib/blm/co/ field_offices/grand_junction_field/PDF.Par.3668.File.dat/Final\%20Wild\%20and\%20Scenic\%20 Eligibility\%20Report\%20original\%20signature\%20web.pdf (last visited April 8, 2009).

${ }^{84}$ U.S.-Parks, Rocky Mountain Nat'l Park-Hydrologic Activity, http://www.usparks.com/ rocky/hydrologic_activity.html (last visited April 3, 2009).

${ }^{85}$ Interview with Bart Miller, Water Program Manager, Western Resource Advocates; Colo. Trout Unlimited, Water Court Finalizes Decree to Benefit Black Canyon of the Gunnison National Park, http://ctunewsblog.wordpress.com/2009/01/08/water-court-finalizes-decree-to-benefit-blackcanyon-of-the-gunnison-national-park/ (last visited April 3, 2009).

${ }^{86}$ See generally Upper Colo. River Endangered Fish Recovery Program, http://www.fws.gov/ coloradoriverrecovery/ (last visited April 3, 2009). 
water suppliers. ${ }^{87}$ Water users and the State have agreed to downstream delivery points for these releases to ensure their protection. ${ }^{88}$

\section{Flows for Recreation}

Between 1999 and 2007, seven decrees were awarded to local governments for flows as high as 1,400 cfs for what are called "recreational in-channel diversions" ("RICD"s). ${ }^{89}$ An RICD is simply a structure (or structures) placed in a stream channel to create the kind of hydraulic features ordinarily found only in whitewater segments. The structures transform stream flows into waves, pools, drops, and eddies for use by kayakers, canoeists, rafters, tubers, and others. They are built in urban areas to provide readily accessible water-based recreation. Such appropriations are not regarded under Colorado law as instream flows because they are based on structural control of water to provide the beneficial use. ${ }^{90}$ They are now governed by specific statutory provisions of Colorado water law. ${ }^{91}$

\section{Summary}

Colorado has actively appropriated water for environmental benefits in streams with important sport fisheries, particularly in high elevation locations. Since 1973, the State has filed instream flow appropriations covering 8,500 stream miles, approximately eight percent of the State's total. ${ }^{92}$ The State has generally worked successfully with federal land management agencies to find acceptable ways to use state law to accomplish federal objectives in a number of instances. It has been a generally constructive participant in efforts to provide flows needed to support endangered species. Recently the legislature has expanded the CWCB's

${ }^{87}$ An effort to adopt a new "upside down" instream flow water right was not successful. Nicole Silk et al., Turning Instream Flow Water Rights Upside Down, 7 RiverS 298 (2000). The state did appropriate a baseflow for protection of the endangered fishes, a rare example of an appropriation for warm-water fish. But the essential higher flows are provided by managed releases from federal and non-federal upstream reservoirs. Id.

${ }^{88}$ By designating a place of use just upstream of the 15 Mile Reach, water can be delivered and administered under the Colorado water rights system independent of the state instream flow program.

89 See Colo. Water Conservation Bd., Decreed RICD Applications, http://cwcb.state.co.us/ WaterSupply/Recreational/DecreedRICDs/ (last visited April 3, 2009); Colo. Rev. STAT. \$37-92102 (5), (6).

${ }^{90}$ Colo. Water Conservation Bd. v. Upper Gunnison River Water Conservancy Dist., 109 P.3d 585 (2005); Glenn E. Porzak et al., Recreation Water Rights: “The Inside Story”, 10 U. DenV. WATER L. REV. 209 (2007) (providing a discussion of the legal and political wrangling over RICDs).

91 Colo. Rev. Stat. $\$$ 37-92-103 (5), (6).

${ }^{92}$ Information on protected stream miles from the Colorado Water Conservation Board. http://cwcb.state.co.us/StreamAndLake/NewAppropriations/. Total Colorado and other western state stream miles from The Montana Watercourse, Water Facts for Mont., http://www. mtwatercourse.org/waterfacts.htm\#miles (last visited Feb. 9, 2009). 
ability to work on flow restoration, including authorization of funding needed to acquire existing water rights for instream flow purposes. As discussed in Part IV, infra, a logical next step would be to allow holders of existing rights to change their rights to environmental flow uses.

\section{Idaho $^{93}$}

\section{Introduction}

Among the Rocky Mountain states Idaho enjoys a relative abundance of water. Its 90,000 miles of rivers and streams carry an average of 86 million acrefeet of water annually. ${ }^{94}$ There are 26,000 miles of fishable streams and 3,100 miles of whitewater on 67 rivers and streams..$^{95}$ Total surface and ground water withdrawals for all uses were 21.8 million acre-feet in $2000 .{ }^{96}$ Irrigation accounted for 19.1 million or about $87 \%$ of the total.

Both as a means of protecting its waters from export to other states and of maintaining important fisheries, recreation, and aesthetic values, Idaho has acted statutorily and administratively to legally protect unappropriated water for instream uses and to help restore flows in dewatered streams. The state has appropriated waters to protect minimum flows, designated protected rivers, and authorized the use of water banks for flow augmentation. More recently, the state, as well as groups such as Trout Unlimited and The Nature Conservancy, have been working to restore flows through a variety of arrangements with water right holders. We look first at the state program for appropriation of water for environmental flows.

\section{Minimum Flow Appropriations}

The Idaho legislature has itself appropriated waters for protection of environmental values and, in 1978, it established a program by which the Idaho

${ }_{93}$ Assistance for this section was provided by Peter Anderson, Trout Unlimited, Idaho; Mark Moulton, Sawtooth National Recreation Area, Idaho; Helen Harrington, Idaho Department of Water Resources; Morgan Case, Idaho Department of Water Resources; Cindy Robertson, Idaho Fish and Game; David Barber, Office of the Attorney General, Idaho; Kimberly Goodman, Trout Unlimited, Idaho; Dean Huibregtse, BLM, Idaho; Mike Gheleta, Attorney, Colorado; and Randy Bramer, Office of General Counsel, U.S. Department of Agriculture, Colorado.

${ }^{4}$ Idaho Water Res. BD., Idaho State Water Plan 26 (1996), available at http://www.idwr. idaho.gov/waterboard/Planning/State_Planning/Documents/StatePlans/SWP1996.pdf (last visited April 3, 2009).

${ }^{95}$ Id. at $79,80$.

${ }^{96}$ USGS, Estimated Uses of Water in the U.S., 2000, Table 2, available at http://pubs.usgs. gov/circ/2004/circ1268/htdocs/table02.html (last visited Feb. 9, 2009) [hereinafter Estimated Uses of Water]. 
Water Resource Board may file for minimum flow rights. ${ }^{97}$ The legislature retains an oversight role and may disapprove permitted rights. Under Idaho law, any person may request the Board to file for a minimum flow right, but only the state may hold such a right. ${ }^{98}$ Initially, most requests came from the Idaho Department of Fish and Game and the Department of Parks and Recreation. In addition, as part of its water basin planning process, the Board itself has identified segments for flow protection. There are now 70 licensed minimum flow rights held by the Board covering 554 miles of stream. ${ }^{99}$ In addition, 212 rights have been established legislatively. And another 11 rights have been permitted and may ripen into licenses. ${ }^{100}$ Idaho established most of its minimum flow rights between 1978 and 1993. The most dramatic addition of minimum flow appropriations by the Board resulted from the 2004 Snake River Water Rights Agreement, resolving the claims of the Nez Perce Tribe and the United States as trustee under the tribe's treaty rights. ${ }^{101}$

The statutory restriction of state ownership of minimum flows serves as the basis for ongoing litigation in which irrigators are suing the Bureau of Reclamation for releases of water from project reservoirs on the Boise River upstream of the state capitol. ${ }^{102}$ The irrigators are arguing the releases are minimum stream flows, and that only the state may authorize such releases. The releases provide water to help meet downstream endangered species needs, but they have also provided a base flow in the river as its passes through the City of Boise.

\section{Protected Rivers}

In 1988 the Idaho legislature authorized the Board to develop comprehensive water plans for individual areas of the state. ${ }^{103}$ Included was authority for the Board to designate "protected rivers," where it determines that the "value of preserving a waterway for particular uses outweighs that of developing the waterway for other

${ }^{97}$ Idaho Code Ann. \$ 42-1501 et seq. (2009). More background is provided in J. Beeman $\&$ K. Arment, Instream Flows in Idaho, in Instream Flow Protection in the West (1989), supra note 2 , at 267 .

98 Idaho Code Ann. \$ 42-1504 (2009).

${ }_{99}$ Minimum Stream Flow Summary, http://www.idwr.idaho.gov/waterboard/Planning/ Minimum\%20Stream\%20Flow/Documents/MSF_for_Web.pdf (last visited May 9, 2008).

${ }^{100}$ A complete listing of minimum stream flow rights is available online at http://www.idwr. idaho.gov/waterboard/Planning/Minimum\%20Stream\%20Flow/Documents/MSF_for_Web.pdf (last visited Jan. 28, 2009).

101 The settlement agreement and related documents are online at http://www.idwr.idaho.gov/ nezperce/index.htm (last visited Feb. 9, 2009).

${ }^{102}$ Personal Communication from David Barber, Deputy Attorney General, Idaho Office of the Attorney General (Apr. 23, 2008).

103 IdAHo Code AnN. \$ 42-1734A (2009). 
beneficial uses ... ." ${ }^{104}$ Protected rivers can either be "natural" or "recreational." No new water development is permitted on natural rivers. To date, the Board has developed 11 such plans that include protected river segments, of which 118 are designated natural. ${ }^{105}$

\section{Water Transactions Program}

Water transactions are focused on changing uses of existing water rights under voluntary agreements to produce enhanced stream flows by reducing diversions in critical stream segments. ${ }^{106}$ The State of Idaho is a partner in the Columbia Basin Water Transactions Program through which funding from the Bonneville Power Administration is used to pay for transactions. This program is part of a much larger effort, led by the Northwest Power and Conservation Council, to help restore the threatened anadromous fisheries in the Columbia Basin. The Idaho program is concentrated in the Upper Salmon Basin and is part of the Watershed Project focusing on stream and habitat improvements. ${ }^{107}$ The Idaho Water Resources Board also receives matching funds through the Pacific Coast Salmon Recovery Fund for certain transactions in the Salmon Basin.

Transactions in Idaho have taken several different forms. Of the 32 transactions between 2003 and 2007, 18 were leases. ${ }^{108}$ Most of the leases were for a single year (or part of a year), but several are for 10-year terms. Increasingly, the preferred form of transaction is an agreement not to divert. In 2007, there were five such agreements ranging in duration from one year to 30 years. One attraction of such agreements is they do not involve a change of use review.

\section{Water Banks}

Water banking has a long history in Idaho, but its use for environmental water emerged in the 1990s as a mechanism by which the Bureau of Reclamation ("Reclamation") could obtain water regarded as necessary to enable its projects in the Snake River Basin to continue to operate without jeopardy to endangered

104 Id. at (4).

105 For a map showing the location of these protected rivers see http://www.idwr.idaho.gov/ waterboard/Planning/Protected\%20Rivers/protected_rivers.htm (last visited Feb. 9, 2009).

106 The Idaho program is part of the larger Columbia Basin Water Transactions Program. Information available online at http://www.cbwtp.org/jsp/cbwtp/program.jsp (last visited Feb. 9 2009).

107 For a map of the area and information about the Upper Salmon program see http://www. idwr.idaho.gov/waterboard/Planning/Water\%20Transaction\%20Program/water_transaction_ program.htm (last visited Feb. 9, 2009).

108 Information provided by Morgan Case, Staff Biologist, Idaho Department of Water Resources, on May 12, 2008. 
salmon. ${ }^{109}$ Because Idaho law did not allow Reclamation to lease water for such purposes, the Idaho legislature specifically authorized its operation. ${ }^{110}$

Since the mid-1990s, Reclamation has been renting water from the Snake, Boise, and Payette rental pools as available to provide up to 427,000 acre-feet of water at times and places needed by the salmon. Reclamation rents storage water on an annual basis from these pools, following the rules and procedures established by the local operating committees. In addition, as part of the 2004 Snake River Settlement (for the Nez Perce), the legislature authorized Reclamation to lease or acquire natural flow water rights for up to 60,000 acre-feet to supplement flows for salmon.

In addition to the rental pools that enable use of stored water, Idaho established a State Bank in 1979. ${ }^{111}$ Direct flow water rights and private storage rights anywhere in the state can be banked and become available for lease by others, including the Water Resources Department, for temporary uses-including to enhance stream flows in locations with a state-established minimum flow. The Board has used the State Bank to lease water under its water transactions program.

\section{Lembi and Wood River Water Banks}

In 2001, the Idaho legislature established a special water supply bank for the Lemhi River. ${ }^{12}$ This legislation established a minimum flow water right at the lower end of the Lemhi near its confluence with the Salmon River, with the intention that the right be supplied not from unappropriated water but from transactions under the bank involving existing upstream water rights. ${ }^{113}$ Provision is made for rental of existing rights through the bank. Transactions are based on an assumed consumptive use of 2.5 acre-feet per acre of irrigated land, and leases may be for partial season, full season, or multi-year periods. No formal change of water right is required for these transactions.

The success of the Lemhi program led the legislature in 2007 to establish a somewhat similar program in the Wood River Basin. ${ }^{114}$ Again the legislature

109 Water Banks in the West, Washington Department of Ecology (2004), at 61 et seq., available at http://www.ecy.wa.gov/pubs/0411011.pdf (last visited Feb. 9, 2009).

${ }^{110}$ IdAHo Code Ann. $\$ 42-1763$ B (2009).

${ }^{111}$ A history of water banking in Idaho is available online at http://www.idwr.idaho.gov/ waterboard/water\%20bank/history_of_bank.htm (last visited Feb. 9, 2009).

112 Idaho Code Ann. \$ 42-1506 (2009).

${ }^{113}$ In this instance, the designated minimum flow could not be met by existing flows. The legislation nevertheless established the flow rate with the intention it would be met through actions involving existing water diversions. Ordinarily under Idaho law, a minimum flow can only be established if existing hydrology supports it.

${ }_{114}$ IdAho Code AnN. \$\$ 42-1508, 42-1765B (2009). 
directed the Board to establish minimum flow rights in a designated reach of the Big Wood and Little Wood rivers, with the desired flows to be met through donations of water rights. The statute does not allow use of the bank for either leasing or purchase of water rights to enhance flows.

\section{Flow Protection on Federal Lands}

Approximately 63\% of Idaho is federally owned and managed. ${ }^{115}$ As part of the Snake River Basin Adjudication, the federal government filed numerous claims for water associated with its lands in this basin. ${ }^{116}$ It prevailed only on its claims under the Wild and Scenic Rivers Act and for the Hells Canyon National Recreation Area. These claims have now been established as water rights under agreement with the State. ${ }^{117}$ In 1990 the State entered into a memorandum of understanding with the Forest Service and the Bureau of Land Management to cooperatively investigate the suitability of streams on these federal lands for Wild and Scenic River designation. ${ }^{118}$ The Idaho Water Resource Board has established minimum flows on many streams located on federal lands and also has established protected rivers on some of these lands.

There are five federally-designated Wild and Scenic Rivers in Idaho: the middle fork of the Clearwater, including the Lochsa and Selway rivers; the headwaters of the Rapid River within the Nez Perce National Forest; the St. Joe River above its confluence with the North Fork in the Idaho Panhandle National Forest; a portion of the mainstem of the Salmon River within the Salmon-Challis National Forest; and 100 miles of the Middle Fork of the Salmon River to its confluence with the main Salmon River. ${ }^{119}$

\section{Summary}

Idaho is fortunate to have some of the nation's most spectacular rivers. Recreation and fishing are an increasingly important part of the state's economy. Nevertheless, irrigated agriculture remains important-particularly in the Snake River Basin where there are significant conflicts between groundwater and surface

115 Congressional Research Service, supra note 76.

116 Potlatch Corp. v. United States, 12 P.3d 1260 (Idaho 2000).

117 In re: SRBA, Case No 39576: Consolidated Subcase No. 75-13316, Wild \& Scenic Rivers Act Claims, (Encompassing Subcases75-133167, 77-11941, 77-138447, 81-11961, 81-10472,8110513, and 8 1-10625); Stipulation and Joint Motion for Order Approving Stipulation and Entry of Partial Decrees (Aug. 20, 2004).

${ }^{118}$ Memorandum of Understanding between the Governor, State of Idaho, and Regional Foresters Northern and Intermountain Regions Forest Service and State Director, Idaho Bureau of Land Management (Feb. 14, 1991).

119 A list of designated Wild and Scenic Rivers in Idaho can be found at http://www.rivers.gov/ wildriverslist.html\#id (last visited Feb. 9, 2009). 
water users. Early enthusiasm for using the minimum flow program to protect unappropriated water in rivers has tapered off. However, in response to specific demonstrated needs the State has shown a willingness to craft tailored legislative responses to facilitate interests in recovery of endangered fish. Water banks now play an important role in facilitating the use of existing water rights for streamflow enhancement. As discussed in the recommendations section, infra, by allowing all parties to make at least temporary use of existing water rights for streamflow enhancement, Idaho could readily advance existing state efforts.

\section{Montana ${ }^{120}$}

\section{Introduction}

Montana is the largest of the Rocky Mountain states, the fourth largest in the country. Its two major river basins, the Upper Missouri and the Upper Columbia, generate or pass through roughly 40 million acre-feet of runoff annually. ${ }^{121}$ Its population of about 900,000 people withdrew about 12 million acre-feet of water for all uses in $2000-10.3$ million for irrigation. ${ }^{122}$

Topographically, Montana is two states: the great plains of the eastern three fifths of the state and the mountainous west. Most of the precipitation is centered in the mountainous region, with distributions ranging from about 34 inches a year in one part of the northwest to about 6 inches in the south central part of the state. ${ }^{123}$ It is a land of big rivers: the Upper Missouri formed by the Jefferson, Madison, and Gallatin rivers and the Yellowstone to the east and the Clark Fork and the Kootenai to the west. There are two congressionally-designated Wild and Scenic Rivers - the three branches of the Flathead River-North Fork, Middle Fork, and that portion of the South Fork above Hungry Horse Reservoir, and a portion of the Missouri as it flows through the Upper Missouri River Breaks National Monument. ${ }^{124}$ As noted by the U.S. Geological Survey:

Instream uses of water for recreation and habitat for fish and wildlife are becoming more important to Montana's rapidly growing tourism industry. Montana's rivers are a popular vacation

${ }^{120}$ Assistance for this section was provided by Laura Ziemer, Trout Unlimited, Montana; Mike McLane, Montana Department of Fish, Wildlife, and Parks; Andy Drummond, Montana Department of Fish, Wildlife, and Parks; and Brianna Randall, Clark Fork Coalition, Montana.

121 USGS, Estimated Uses of Water in Montana, 2000.

122 Id. at 8 .

123 Western Regional Climate Center, Climate of Montana, http://www.wrcc.dri.edu/ narratives/MONTANA.htm (last visited April 6, 2009).

${ }^{124}$ U.S. Fish and Wildlife Service, Designated Wild \& Scenic Rivers, http://www.rivers.gov/ wildriverslist.html (last visited Feb. 9, 2009). 
destination for float trips, fishing, and wildlife viewing. Guided river trips are popular on many Montana rivers including the Yellowstone, Smith, Flathead, Bighorn, and Missouri Rivers. ${ }^{125}$

Given the relative abundance of water-at least in the western part of the state-and the importance of instream uses for recreation, Montana has been active in setting aside unappropriated water for protection of environmental flows and in restoring dewatered rivers with valuable fisheries. Discussed here are state appropriations and reservations of water as well as acquisitions and leases of water for instream uses.

\section{Appropriations and Reservations}

In 1969 the Montana legislature authorized the State Fish and Game Commission to appropriate the waters in 12 "blue ribbon" trout streams for preservation of fish and wildlife habitat. ${ }^{126}$ Then, in 1973, the legislature established a process whereby unappropriated water in Montana streams and rivers could be reserved for existing or future beneficial uses or to "maintain a minimum flow, level, or quality of water ...."127 Instream flow reservations cannot exceed $50 \%$ of the average annual flow. ${ }^{128}$ The Department of Natural Resources and Conservation ("DNRC") has used this process to establish hundreds of instream flow reservations in the Upper and Lower Missouri and Yellowstone basins. ${ }^{129}$ Today, the Montana Department of Fish, Wildlife, and Parks ("DFWP") holds 376 reservations on 331 streams. ${ }^{130}$ The Montana Department of Environmental Quality holds reservations for water quality purposes. And the Bureau of Land Management has obtained reservations on 31 streams crossing its lands in the Upper Missouri River Basin.

Reservations are not a perpetual commitment of water. By statute, the Department must review all reservations every ten years. ${ }^{131}$ This review examines due diligence in perfection of the state-based water reservation and a

125 Estimated Uses of Water in Montana, supra note 121, at 8.

126 M. McKinney, Instream Flow Policy in Montana: A History and Blueprint for the Future, in Instream Flow Protection in the West (rev. ed. 1993), supra note 2, at 15-4.

127 Mont. Code Ann. \$ 85-2-316(1) (2009).

128 "The department shall limit any state water reservations after May 9, 1979, for maintenance of minimum flow, level, or quality of water that it awards at any point on a stream or river to a maximum of $50 \%$ of the average annual flow of record on gauged streams. Ungauged streams are not subject to the limit under this subsection.” MonT. Code ANN. \$ 85-2-316(6) (2009).

${ }^{129}$ Montana went through major basin processes for the Yellowstone and the Upper and Lower Missouri rivers, identifying flows to be protected and resulting in reservation orders in 1979, 1992 , and 1994.

${ }^{130}$ Personal Communication from Andy Brummond, Water Resources Specialist, Montana Department of Fish, Wildlife, and Parks (May 7, 2008).

131 Mont. Code Ann. \$ 85-2-316(10) (2009). 
determination of use to see if the right is meeting its prescribed objective. Such review provides information upon which the Department may extend, modify, or revoke the reservation. The Department may modify an instream flow reservation every five years. In fact, however, no reservations have yet been modified. Instead, at least those reservations held by DFWP are being managed like water rights. Especially since the drought period around 2000, DFWP has been expanding its monitoring efforts and has been working with junior appropriators to protect instream reserved flows. ${ }^{132}$

\section{Compact Agreements for Reserved Rights}

In 1979, the Montana legislature established a Reserved Water Rights Compact Commission to negotiate resolution of federal and tribal claims to reserved water rights. ${ }^{133}$ Federal lands account for about 30\% of Montana. ${ }^{134}$ Through the commission process, Montana has entered into compacts-incorporated into statute - with the National Park Service (1995), the Bureau of Land Management (1997), the U.S. Fish and Wildlife Service (1997, 1999, 2007), and the U.S. Forest Service (2007). ${ }^{135}$ The primary intent of the compacts is to resolve federal water claims based on the reserved rights doctrine. ${ }^{136}$

The recent compact with the Forest Service illustrates how federal instream water interests are addressed. In addition to recognizing a reserved right for the South Flathead Wild and Scenic River, the compact creates state water rights for instream flows on 77 stream segments located within national forests and an in-place right for one fen. ${ }^{137}$ In addition, provision is made for the Forest Service to use the State's reservation process to seek additional instream flow protection. ${ }^{138}$ In return, the United States withdrew its claims for federal reserved rights in the state adjudication process.

The State also has established compacts that include water for fish and wildlife and ceremonial purposes with the Blackfeet, Chippewa Cree, Crow, Northern

132 Telephone Interview with Andy Brummond and Mike McLane, Water Resources Specialists, Montana Department of Fish, Wildlife, and Parks (Apr. 25, 2008).

${ }^{133}$ Information about the commission is available online at http://dnrc.mt.gov/rwrcc/default. asp (last visited Feb. 10, 2009).

134 Congressional Research Service, supra note 76. 6, 2009).

135 All compacts are available online at http://dnrc.mt.gov/rwrcc/default.asp (last visited April

136 This doctrine provides a right to water necessary to fulfill the primary purposes of federal and tribal lands reserved by Congress or the President from entry under the public land disposal laws. This right, regarded as established at the time the land reservation was made, exists independent of state water law. See, e.g., United States v. New Mexico, 438 U.S. 696 (1978).

137 Mont. Code Ann. \$ 85-20-1401 (2009).

138 Mont. Code Ann. \$ 85-2-320 (2009). 
Cheyenne, the Assiniboine and Sioux tribes of the Fort Peck Reservation, and the Gros Vente and Assiniboine tribes of the Fort Belknap Reservation. ${ }^{139}$

\section{Leasing and Acquisition}

The Montana legislature established a limited leasing program for instream flows in 1989, authorizing the DFWP to enter into leases on four streams. ${ }^{140}$ It expanded the program to additional streams in 1991 and again in 1993. In 1995, the legislature authorized a pilot leasing program in the Upper Clark Fork, allowing private groups or individuals to lease water for instream flows. Also, for the first time the legislature authorized the change of use of an existing right to instream flow purposes. At present, Montana continues its state leasing program while also allowing private parties to lease water for instream purposes or to convert their diversionary rights. Existing water rights may be changed temporarily or, in limited instances, permanently. Only the DFWP and the Forest Service are specifically authorized to permanently change the use of owned rights to instream flow purposes. ${ }^{141}$ DFWP leases are limited to ten year terms but may be renewed indefinitely (assuming the authorizing statute stays in place); leases for water that comes from a water conservation program may be for up to 30 years. DFWP also may contract for the release of storage water for flow enhancement.

The evolution of instream leasing and change of water right law in Montana is instructive. It reflects an initially cautious view that gradually gave way to substantial support, including opening the process to non-governmental entities. This growing level of political support emerged out of both positive experiences under the initial leasing program and from the development of a diverse coalition of interests, including agriculture, that grew to support this voluntary approach to flow restoration. ${ }^{142}$

In addition to DFWP, Trout Unlimited and the Montana Water Trust have been actively engaged in establishing instream flow leases. The Water Trust has concentrated its efforts on tributaries where modest improvements in stream flows can provide significant fishery benefits. ${ }^{143}$ More recently, attention has turned to

139 These compacts can be accessed at the Montana Reserved Water Rights Compact Commission web site, http://dnrc.mt.gov/rwrcc/default.asp\# (last visited April 6, 2009).

${ }^{140}$ An excellent summary of the history of the leasing program can be found in Trout Unlimited, Private Water Leasing: A Montana Approach, available online at http://www.tu.org/atf/ cf/\%7B0D18ECB7-7347-445B-A38E-65B282BBBD8A\%7D/MT_WaterReport.pdf (last visited April 6, 2009). See also John Ferguson et al., Keeping Fish Wet in Montana: Private Water Leasing: Working Within the Prior Appropriation System to Restore Streamflows, 27 PUB. LAND \& RESOURCES L. Rev. 1 (2006).

${ }^{141}$ Mont. Code Ann $\$ \$ 85-2-320,-436$ (2009).

142 Private Water Leasing, supra note 140.

${ }_{143}$ Explained at http://www.montanawatertrust.org/our-approach/ourappoach.html (last visited Feb. 10, 2009). 
leases of storage water because of the ability to shape releases of water to meet instream flow needs. Trout Unlimited has emphasized flow enhancement in the context of stream habitat restoration. ${ }^{144}$

\section{Drought Management Plans}

One of the more notable tools for instream flow protection in Montana is the voluntary drought management plan. An example of outcomes that can sometimes emerge from collaborative watershed processes, drought plans have been developed in several parts of Montana to protect fisheries during water shortages. ${ }^{145}$ These efforts emphasize education, monitoring, and primarily voluntary action. For example, a stakeholder group, the Blackfoot Challenge, worked out voluntary agreements among water diverters in the drought years of 2000 and 2001 to maintain enough flow in the Blackfoot River to protect the fish during the low flow period. ${ }^{146}$ They are now moving to expand the scope of conservation activities under a long-term plan.

\section{Groundwater Development and Instream Flows}

Pumping of ground water from alluvial aquifers, especially from wells close to a stream, can directly reduce flows in that stream. Montana law recognizes the potential hydrologic connection between surface water and ground water. ${ }^{147}$ However, the DNRC was allowing new groundwater development in basins designated as closed to new surface water appropriations so long as pumping would not immediately reduce surface flows. Montana Trout Unlimited successfully challenged this administrative interpretation of Montana law, ${ }^{148}$ and the legislature responded with changes in the statute requiring new groundwater applications in closed basins to be accompanied by an assessment of potential depletions of surface water. ${ }^{149}$

\section{Summary}

Montana appears to have actively embraced the importance of protecting and restoring stream flows, particularly in the well-watered mountainous part of the

${ }_{144}$ Personal Communication from Laura Ziemer, Montana Director, Western Water Project, Trout Unlimited (May 7, 2008).

145 Telephone Interview with Mike McLane \& Andy Brummond, Water Resources Specialists, Montana Department of Fish, Wildlife, and Parks (Apr. 25, 2008).

146 For more information see www.blackfootchallenge.org/ (last visited April 6, 2009).

147 L. Ziemer et al., Ground Water Management in Montana: On the Road from Beleaguered Law to Science-Based Policy, 27 Pub. Land \& Resources L. Rev. 75 (2006).

148 Montana Trout Unlimited v. Montana Dep't. of Natural Res. \& Conservation, 133 P.3d 224 (Mont. 2006).

149 Mont. Code Ann \$ 85-2-360(1) (2009). 
state. In part, this commitment reflects the importance of fishing and recreation to the state's economy. In part, it reflects an availability of water sometimes in excess of out-of-stream demands. The reservation process has been used extensively to protect flows east of the continental divide. The compact process has been used successfully to negotiate water right agreements with federal land management agencies and tribes. Some Montanans have demonstrated an ability to share water in times of drought to benefit fisheries. Willingness to enable non-governmental entities to hold water rights for instream flows has brought more players to the process, with additional resources. A possible next step would be to allow permanent changes of water rights for environmental flow purposes.

\section{E. Nevada ${ }^{150}$}

\section{Introduction}

Nevada is the driest of our study states, with an average annual precipitation of about nine inches. ${ }^{151}$ It is almost totally located between the rain shadow of the Sierra Nevada mountains to the west and the Rockies to the east. The state's complex basin and range topography results in 14 different hydrologic units, only two of which (the Bear and the Colorado) drain outside the state. Perennial streams are few in Nevada. The Truckee, Carson, and Walker rivers originate in the Sierra Nevada mountains of California and flow east into Nevada in the vicinity of Reno. The Humboldt originates and ends within the state. The Colorado, as it flows south to Mexico, forms a portion of the state's eastern border near Las Vegas. The total estimated yield from Nevada's surface sources is about 3.2 million acrefeet annually. ${ }^{152}$ The USGS estimates Nevada users withdrew about 3.1 million acre-feet of water for all purposes in 2000, about 2.3 million for irrigation. ${ }^{153}$

Nevada's unique landscapes and hydrology support a diverse array of natural systems. Extensive use of the state's limited water resources inevitably has taken its toll, however. According to the Nevada Water Plan, 11 of the state's native species of fish are extinct or extirpated, and 23 are listed as either threatened or endangered under the Federal Endangered Species Act. ${ }^{154}$ More than half of the state's wetlands are gone.

${ }^{150}$ Assistance for this section was provided by Richard Rimes, USFWS, Nevada; Elmer Bull, Nevada Parks and Wildlife; Carol Grenier, Bureau of Reclamation, Nevada; and Michael Cameron, TNC, Nevada.

151 The Nevada State Water Plan can be found at http://water.nv.gov/WaterPlanning/watplan/pt1-tbfg.cfm (last visited April 6, 2009).

152 See id. at 4-16.

153 Estimated Uses of Water, supra note 96.

154 Id. at 3B-2. 
There is no state program for protection of environmental flows in Nevada. Nevada law, however, authorizes appropriation of water for recreational uses, a provision that has been interpreted by the state's Supreme Court to include wildlife, and does not limit who may file for such appropriations. ${ }^{155}$ In 2007, the legislature authorized the temporary conversion of irrigation rights to wildlife purposes or to improve the quality or flow of water. ${ }^{156}$ Environmental water needs have been met primarily through acquisition of existing rights and their conversion to wildlife purposes. The State has focused its attention on state wildlife areas, including their water-related requirements. Managed releases of water from Reclamation reservoirs also have been important for stream flows on the Truckee River.

\section{Environmental Water in the Truckee and Carson Basins}

Concerns about the threatened Lahontan cutthroat trout and the endangered cui-ui in the Truckee River and Pyramid Lake, and the loss of wetlands in the lower Carson basin, instigated a series of actions that led to the Truckee-Carson/ Pyramid Lake Water Rights Settlement Act of $1990 .{ }^{157}$ One of the nation's first reclamation projects, Newlands diverts water out of the Truckee River to irrigate agricultural lands. Much of the unconsumed water never returned to the Truckee because most of the irrigated lands are in the Carson River watershed. Water levels in Pyramid Lake, the terminus of the Truckee River, had declined to the point that native fish in the lake could not swim up into the river to spawn. One of the programs established under the Settlement Act involved purchasing water rights in the Truckee portion of the Newlands Project and retiring their irrigation use so that the water could remain instream. ${ }^{158}$ In addition, the States of California and Nevada, the Pyramid Lake Paiute Tribe, the major water users, and the federal government have now agreed to the Truckee River Operating Agreement, ${ }^{159}$ governing storage and release of water in upstream Reclamation reservoirs. Releases are used, in part, to improve stream flows through the Reno area and into Pyramid Lake.

Reduced diversions from the Truckee led to reduced return flows into the Lahontan Valley, the terminus of the Carson River. The Lahontan Valley contains Nevada's most important wetlands. The Settlement Act set up a water rights acquisition program to provide additional water for the wetlands in the Stillwater

155 State v. Morros, 766 P.2d 263 (Nev. 1988).

156 Nev. Rev. STAT. $\$ 533.0243$ (2009).

157 Truckee Carson/Pyramid Lake Water Rights Settlement Act, Title II of P.L. 101-618, 1990 Stat. 3084 (1990).

158 Id. \$ 206(A) (1990).

15973 Fed. Reg. 74,031-01 (Dec. 5, 2008). Information about the agreement is available online at http://www.usbr.gov/mp/troa/ (last visited Feb. 10, 2009). 
National Wildlife Refuge and Carson Lake. The U.S. Fish and Wildlife Service determined in 1996 that 75,000 acre-feet of water would be needed. ${ }^{160}$ After 12 years, FWS, in partnership with the State of Nevada, The Nature Conservancy, the Nevada Waterfowl Association, the Bureau of Indian Affairs, and the Bureau of Reclamation, have acquired about 37,800 acre-feet of water from the Carson Division of the Newlands Project: 27,100 acre-feet by FWS, 1,800 acre-feet by BIA, and 8,900 acre-feet by the state and NWA. In addition, FWS has purchased 4,300 acre-feet of water from users in another segment of the Carson River and received 2,900 acre-feet from the Navy. ${ }^{161}$ In short, they are just halfway to their goal.

In addition to the ordinary challenges involved in acquiring water rights, transactions have been impeded by a series of disputes that have involved extensive litigation, including unresolved questions about the actual quantity of transferable water. $^{162}$

\section{State Wildlife Management Areas}

The Nevada Department of Wildlife manages nine wildlife management areas around the state, some of which contain wetland acreage and reservoirs for which surface and groundwater rights have been obtained. For example, the Mason Valley WMA is located on formerly irrigated land adjacent to the Walker River purchased by the state together with the associated water rights. ${ }^{163}$ Water rights at some WMAs depend on flood flows, irrigation tail water, or subsurface drains. An example is the WMA located in the Humboldt Sink at the terminus of the Humboldt River.

The State also manages the Carson Lake and Pasture, an area of wetlands in the southeast corner of the Lahontan Valley. The Department of Wildlife has been purchasing water rights from upstream irrigators for use in Carson Lake and Pasture, similar to the efforts by the FWS to acquire rights for the Stillwater National Wildlife Refuge. To date, the Department has acquired 8,300 acre-feet of water, based on the duty of water of 3.5 acre-feet per acre established by court decree. ${ }^{164}$ However, only 7,000 acre-feet has been transferred pending resolution of the legally transferable quantity of water.

${ }^{160}$ Personal Communication from Richard Grimes, Supervising Realty Specialist, Stillwater National Wildlife Refuge, U.S. Fish and Wildlife Service (May 21, 2008).

161 Id.

162 Id.

163 Telephone Interview with Elmer Bull, Wildlife Staff Specialist, Nevada Department of Wildlife (June 12, 2008).

${ }^{164} \mathrm{Id}$. 


\section{Walker Lake}

Walker Lake sits at the terminus of the Walker River and is an enclosed basin. Upstream water uses have severely diminished flows into the lake; the lake's surface elevation has dropped 120 feet from the level that existed 100 years ago, and the volume of water in the lake has declined approximately 80\%. ${ }^{165}$ Among other effects, the salinity of the water has increased to levels that threaten the ability of native fish, including the listed Lahontan cutthroat trout, to survive.

Under the sponsorship of Senator Harry Reid, Congress has established and funded a Desert Terminal Lakes program that includes funds to acquire water rights from Walker River users and allow that water to remain instream to the lake. The program has established a target of adding 50,000 acre-feet per year to the lake through acquisitions.

\section{Summary}

Supplies of water in Nevada are limited, and population-especially in the Las Vegas area-is growing rapidly. Opportunities for protection of water-dependent ecosystems are limited. While the State has taken some actions, especially in association with its wildlife management areas, most of the work to protect waterbased environmental values has been accomplished under federal management and funding. Recent legislative action to authorize temporary transfers for environmental benefits provides an important additional tool. In addition, the State may wish to establish a program for environmental flow restoration and protection.

\section{F. New Mexico ${ }^{166}$}

\section{Introduction}

New Mexico is a semi-arid state, with average annual precipitation of about 14 inches. ${ }^{167}$ Relatively few streams are perennial. The major perennial rivers including the Rio Grande and the Pecos are substantially regulated by dams. New Mexico's population of somewhat less than two million people withdrew 3.6

165 Personal Communication from Carol Grenier, Desert Terminal Lakes Program Manager, U.S. Bureau of Reclamation (June 12, 2008).

166 Assistance with this section was provided by Kyle Harwood, Harwood Consulting, Santa Fe, NM; Adrian Oglesby, TNC, NM; Steve Harris, Rio Grande Restoration, NM; Lee Brown, Emeritus Professor, University of New Mexico, NM; Denise Fort, Professor of Law, University of New Mexico; Beth Bardwell, World Wildlife Fund, New Mexico; and Josh Mann, Interstate Stream Commission.

167 New Mexico Climate Center, Climate of New Mexico, http://weather.nmsu.edu/News/ climate-in-NM.htm (last visited April 6, 2009). 
million acre-feet of water in 2000, 3.2 million for irrigation. ${ }^{168}$ More than $40 \%$ of withdrawals came from ground water.

Protection of water for environmental purposes has not historically been a priority for New Mexico. Thus there is no state program for protecting environmental flows, despite several attempts to legislatively establish such a program. Nor has a new water right for environmental flows yet been approved, although the New Mexico Attorney General has determined that an existing right can be changed to instream flow under state water law. ${ }^{169}$ There are four congressionally-designated Wild and Scenic River segments in New Mexico: the very northern portion of the Rio Grande as it enters the state, the Rio Chama below El Vado Dam for 24 miles, the East Fork of the Jemez River from the boundary of the Santa Fe National Forest to the confluence with the Rio San Antonio, and the Pecos from its headwaters downstream for 20 miles. ${ }^{170}$ Flows on the Rio Chama are managed by the Bureau of Reclamation to provide rafting opportunities. ${ }^{171}$ The U.S. attempted unsuccessfully in the 1970s to obtain judicial recognition of instream flow reserved rights for streams in the Gila National Forest. ${ }^{172}$

Our discussion begins with a look at the recently established Strategic Water Reserve and other initiatives suggesting an increasing interest in river restoration. Then we look at several places in the state in which there are active efforts underway involving flow restoration. The needs of endangered species have been a primary driver of water for the environment in New Mexico.

\section{Strategic Water Reserve}

Inability to gain legislative support for an environmental flow program prompted development of an alternative strategy, based loosely on the idea of the strategic petroleum reserve. The concept emerged from a Santa Fe nonprofit called Think New Mexico. In the legislative process it was expanded beyond rivers to include ground water, named the Strategic Water Reserve, and became law in 2005. ${ }^{173}$ The Interstate Stream Commission is authorized to acquire water or water rights, permanently or temporarily, to assist the state either in meeting its

${ }^{168}$ Estimated Uses of Water, supra note 96.

169 Opinion of the Attorney General, Opinion No. 98-01 (Mar. 27, 1998).

${ }^{170}$ U.S. Fish and Wildlife Service, Designated Wild \& Scenic Rivers, http://www.rivers.gov/ wildriverslist.html (last visited April 6, 2009).

${ }^{171}$ U.S. Bureau of Reclamation, Operations Fact Sheet for El Vado Dam and Reservoir, http:// www.usbr.gov/uc/albuq/water/SanJuanChama/Reservoirs/fs/sjc_elvado.html (last visited April 6, 2009).

172 United States v. New Mexico, 438 U.S. 696 (1978).

173 N.M. STAT. $\$ 72-14-3.3$ (2009). 
interstate water delivery obligations or to benefit protected species or species at risk. The program received initial funding of $\$ 2.8$ million; another $\$ 2$ million was added in 2006. Its first use was in the Pecos River.

In 2007, the governor's office and the legislature established the River Ecosystem Restoration Initiative. The legislature has provided funding for grants to entities engaged in a variety of river restoration activities. ${ }^{174}$

\section{Flow Improvements in the Pecos River}

The Pecos River originates in the mountains of northern New Mexico and flows south to its junction with the Rio Grande in Texas. Its modest water supply is shared between users in New Mexico and Texas. The major use in New Mexico is for irrigated agriculture, much of that in the Carlsbad Irrigation District served by the Federal Carlsbad Project. New Mexico has worked to better manage irrigation water use, and even to retire some uses, to help meet its compact water delivery obligations to Texas.

The Pecos bluntnose shiner is listed as threatened under the Endangered Species Act. ${ }^{175}$ Operations of Reclamation's Carlsbad Project were determined to jeopardize the species' continued existence in $1991 .{ }^{176}$ Reclamation has been working to reoperate its facilities, particularly Sumner Dam, to benefit the fish. It has also been acquiring water rights to offset the reduction in deliveries resulting from these additional releases.

The Interstate Stream Commission ("ISC") has used the Strategic Water Reserve to acquire both surface water and groundwater rights in the Pecos to assist in state efforts to meet compact obligations and to enhance flows for the shiner. ${ }^{177}$ In addition to retiring irrigation uses, the ISC has acquired groundwater rights that can be pumped to the river if necessary for compact deliveries. The ISC also has acquired groundwater rights and constructed a pipeline to the river to be able to supplement flows just above the shiner's designated critical habitat.

${ }^{174}$ Information about this initiative is available at http://www.nmenv.state.nm.us/swqb/reri/ index.html (last visited April 6, 2009).

175 U.S. Fish and Wildlife Service, Environmental Conservation Online System, Species Profile for Pecos bluntnose shiner, http://ecos.fws.gov/speciesProfile/SpeciesReport.do?spcode=E04F (last visited April 6, 2009).

${ }^{176} \mathrm{Id}$.

177 Telephone Interview with Josh Mann, Special Assistant Attorney General, Interstate Stream Commission (June 6, 2008). 


\section{Enhancing Flows in the Middle Rio Grande}

The Rio Grande as it moves south out of the mountains towards Elephant Butte Reservoir is a heavily committed river. Much of its water must go to Texas, an obligation that constrains new upstream uses. Historic uses, especially for irrigation, take most of New Mexico's share. With the listing of the Rio Grande silvery minnow as an endangered species in 1994, water managers faced the challenge of factoring in the flow requirements of this fish.

In 2003, following a series of dry years with large stretches of the river going dry, the U.S. Fish and Wildlife Service issued a biological opinion finding that Bureau of Reclamation water operations were jeopardizing the continued existence of the silvery minnow. As a reasonable and prudent alternative, FWS proposed operations over the following ten-year period that would ensure a sufficient spring spike flow necessary to induce the minnow to spawn and flows through the year that would avoid drying up the river in the minnow's designated critical habitat. Reclamation determined, however, it did not have the ability within its legal discretion to make these operational changes. In subsequent litigation, Federal District Court Judge Parker decided that Reclamation was obligated by the Endangered Species Act to modify its operations as necessary to prevent further endangering the minnow's existence. ${ }^{178}$ Using a rider to an appropriation bill, however, Senator Domenici legislatively declared that Reclamation operations complied with the ESA, thus mooting Judge Parker's decision. ${ }^{179}$

There is strong interest in using the Strategic Water Reserve as the mechanism for acquiring water rights to improve flows in the Middle Rio Grande. ${ }^{180}$ Federal and state funds are available for such acquisitions, and the Interstate Stream Commission has instituted a process for putting an acquisition program in place.

\section{Summary}

New Mexico is moving cautiously toward protecting a portion of its water for environmental purposes. In this fully appropriated state, environmental water will have to come primarily by retiring existing consumptive uses. The Strategic Water Reserve now provides a much needed mechanism for this process, though its use is limited to addressing needs of endangered species. Assuming experience

${ }^{178}$ Rio Grande Silvery Minnow v. Keys, 469 F. Supp. 2d 1003 (D.N.M. 2005).

179 Press Release, WildEarth Guardians, Environmental Groups Oppose Domenici Rider; Offer to Permanently Put San Juan-Chama Water Off Limits; Vow Not To Seek San Juan-Chama Water This Year (July 16, 2003), available at http://www.wildearthguardians.org/library/paper. asp?nMode=1\&nLibraryID=181 (last visited April 6, 2009).

180 Telephone Interview with Kyle Harwood, Principal, Harwood Consulting, Santa Fe, NM (June 6, 2008). 
with the Strategic Water Reserve is positive, New Mexico may want to consider authorizing its use beyond endangered species and enabling parties to participate in its use in addition to the Interstate Stream Commission.

\section{G. Utah ${ }^{181}$}

\section{Introduction}

Utah is an arid state; its average annual precipitation of about 13 inches is the second lowest in the country (after Nevada). ${ }^{182}$ The average annual usable water supply is about seven million acre-feet. ${ }^{183}$ Yields are greatest in the Bear, Jordan, Weber, and Sevier River basins. Evaporation from the Great Salt Lake accounts for depletions of about three million acre-feet annually. The Utah Water Plan estimates that remaining developable water is about 790,000 acre-feet. According to the USGS, total withdrawals in 2000 were about 5.5 million acre-feet, about 4.3 million for irrigation. ${ }^{184}$

Utah does not have a program for appropriating water for environmental flows, but its statutes do make some provision for enabling existing rights to be changed to instream flow purposes. Utah has cooperated with the U.S. Fish and Wildlife Service and others in implementation of recovery efforts for endangered native fishes in the Green River. Perhaps the major flow protection efforts in the state are occurring in connection with the Federal Central Utah Project. We begin with a discussion of the state's instream flow program.

\section{State Instream Flow Program}

In 1986, the Utah legislature enabled protection of instream flows by authorizing either the Utah Division of Water Resources or the Division of Parks and Recreation to file for temporary or permanent changes of rights owned by either Division for instream flow purposes. ${ }^{185}$ New appropriations are not authorized. Instream purposes are the propagation of fish, public recreation, or the reasonable preservation or enhancement of the natural stream environment. The divisions may change a donated right to instream use, but may only purchase

181 Assistance with this section was provided by Kirk Dahle, Trout Unlimited, Utah; Tim Hawkes, formerly with Trout Unlimited, Utah; Paul Abate, USFWS, Utah; Dale Hepworth, consultant to Trout Unlimited, Utah; Rick Larsen, Utah Fish and Game, Utah; and Mark Holden, Utah Reclamation Mitigation and Conservation Commission, Utah.

182 Utah Water Plan, available at http://www.water.utah.gov/waterplan/uwrpff/Chp-02b. htm\#20 (last visited April 6, 2009).

183 Id. at Table 3.

${ }^{184}$ Estimated Uses of Water, supra note 96.

185 Now codified at UtaH Code Ann. \$73-3-30 (2009). 
rights with funding specifically appropriated for that purpose. As of 2005, only four rights had been changed in use under this provision. ${ }^{186}$

The Utah legislature in 2008 authorized "fishing groups" to file a change of use to instream flows for an existing right for up to 10 years to protect or restore habitat for native trout. ${ }^{187}$ This legislation resulted from several years of discussions among a variety of interests, spearheaded by Trout Unlimited. ${ }^{188}$ The legislation reflects necessary compromises, including its limitation to places where there is a process for protection of native cutthroat trout, its restriction to temporary changes, and its sunset in 10 years. Importantly, however, it enables groups such as Trout Unlimited to lease or purchase water rights and temporarily change their use to instream flows.

\section{Upper Colorado River Recovery Program}

The flows of the Green River below Flaming Gorge Reservoir are now managed by the Bureau of Reclamation, in part, under a detailed plan designed by the U.S. Fish and Wildlife Service to maintain habitat conditions believed necessary to recover populations of endangered fishes. ${ }^{189}$ Flaming Gorge serves primarily to help the Upper Basin meet its delivery obligations to the Lower Basin under the Colorado River Compact. Historically, the dam was operated to maximize hydropower revenues. Releases now are managed as feasible to meet the spawning and reproduction needs of these fish and are varied according to water availability in a given year.

\section{Mitigation for the Central Utah Project}

As part of the 1992 Central Utah Completion Act, Congress established the Utah Reclamation Mitigation and Conservation Commission and tasked it with, among other things, using appropriated funds to acquire water rights necessary to improve stream flows in the Strawberry River and Provo River basins. ${ }^{190}$ The mitigation plan describes the Commission's efforts to purchase water rights in the Lower Provo River for conversion to instream flows. The objective is to be able

186 Charney, supra note 2, at 124 Appendix B.

187 H.B. 117, codified at UTAH CODE AnN. \$ 73-3-30(3) (2009).

188 Telephone Interview with Tim Hawkes, formerly Director of Utah Water Project, Trout Unlimited, Utah (May 5, 2008).

189 U.S. Bureau of Reclamation, Flaming Gorge Dam Environmental Impact Statement, Background, http://www.usbr.gov/uc/provo/rm/fgeis/fgeis_background.html (last visited Feb. 10, 2009).

190 Information about the Commission and its work can be found at http://www. mitigationcommission.gov/aboutus/aboutus.html (last visited April 6, 2009). 
to maintain a minimum flow of 75 cubic feet per second into Utah Lake. Out of the total federal funding of over $\$ 100$ million for these mitigation projects, approximately $\$ 15$ million is committed to purchase water rights in the Lower Provo.

\section{Federal Reserved Rights for the Virgin River}

The Virgin River flows south from its headwaters into Zion National Park on its way to the Colorado River. The United States and the State of Utah negotiated a settlement of federal reserved rights claims for the park in 1996. ${ }^{191}$ Under the agreement, the U.S. subordinated its rights to all existing upstream water rights in return for a cap on future depletions. The expectation is that this cap will ensure the continuance of stream flows into the park.

\section{Summary}

Utah has shown little enthusiasm for setting water aside for environmental flow purposes. State agencies have made limited use of the instream flow program, apparently because the legislature has not made funds available to acquire existing water rights. Most examples of instream flow protection to date in the state are the result of federal action. The new opportunity for fishing groups to lease water for native trout opens the door for nonprofits to play a role in streamflow protection. Perhaps if this program proves successful, Utah will consider its expansion.

\section{H. Wyoming 192}

\section{Introduction}

Wyoming is a large state with few people. Precipitation is limited, except in the mountainous areas. ${ }^{193}$ Most of the state is within the Missouri River Basin, including such significant rivers as the Yellowstone, Wind/Big Horn, and the North Platte. The Green River is a major tributary to the Colorado. The Snake River originates in Wyoming and flows west to the Columbia. The Bear River begins in Wyoming and flows into the Great Basin and Great Salt Lake. Average annual runoff is about 17 million acre-feet. ${ }^{194}$ The USGS estimated total water withdrawals in Wyoming in 2000 to be about 5.8 million acre-feet, with

191 Zion National Park Water Rights Settlement Agreement, Dec. 4, 1996, available at http:// wcwcd.state.ut.us/Agreements/Zion\%20National\%20Park.pdf (last visited April 6, 2009).

192 Assistance with this section was provided by Tom Annear, Wyoming Game \& Fish Department; Scott Yates, Trout Unlimited, Wyoming; Jeff Fassett, former state engineer, Wyoming; Anne MacKinnon, Wyoming; and Gary Collins, Governor's Office, Wyoming.

193 Wyoming Water Plan, http://waterplan.wrds.uwyo.edu/fwp/ (last visited March 29, 2009).

194 Id. 
irrigation accounting for about 5 million acre-feet. ${ }^{195}$ There are about 21,000 miles of fishable streams in the state, about half on private lands, supporting a considerable recreational economy. ${ }^{196}$

Wyoming has taken a measured approach to protection of environmental flows. State law limits such dedications of water to use for fisheries. State policy is to "focus on the most popular stream fisheries, streams located on public lands, and streams with existing flow agreements under other authorities (such as special use permits)." ${ }^{\prime 197}$ In addition, instream flows have received protection under federal law (e.g., Wild and Scenic Rivers) and through water management operations involving Bureau of Reclamation facilities. We begin with consideration of the state instream flow program.

\section{The State Instream Flow Program}

The Wyoming legislature established a program for protection of instream flows in 1986. ${ }^{198}$ Wyoming's Department of Game and Fish identifies the location and quantifies the desired flows and then passes this information to the Wyoming Water Development Commission, which determines whether to file an application with the State Engineer and the Board of Control. ${ }^{199}$ The statutorily-defined purpose of the appropriation is to maintain or improve an existing fishery. ${ }^{200} \mathrm{The}$ appropriated flow is to be the minimum necessary for that purpose. In addition, the State may acquire an existing water right for the purpose of providing instream flows. It has not yet used this authority. ${ }^{201}$

As of January 2008, 101 applications had been filed with the State Engineer. ${ }^{202}$ Seventy-four permits have been issued, covering more than 300 stream miles. Most of the rights are clustered in a few areas of the state. These segments primarily

195 Estimated Uses of Water, supra note 96.

196 Trout Unlimited, The Economic Value of Healthy Fisheries in Wyoming, January 2005, available at http://www.tu.org/atf/cf/\%7B0D18ECB7-7347-445B-A38E-65B282BBBD8A\%7D/ Ecomonics_Fisheries_WY.pdf (last visited April 6, 2009).

197 Wyoming Game \& Fish Department, Water Management Unit Five-Year Plan; 2006 to 2010, 2006.

198 Wyo. Stat. Ann. $\$ 41-3-1001$ et seq. More background is provided in Gordon W. Fassett, Wyoming's Instream Flow Law, Instream Flow Protection in the West (1989), supra note 2, at 401.

199 See http://wwdc.state.wy.us/instream_flows/instream_flows.html (last visited Jan. 28, 2009).

200 WYO. STAT. AnN. \$ 41-3-1001(c).

201 Telephone interview with Tom Annear, Instream Flow Supervisor, Wyoming Department of Game \& Fish (April 29, 2008).

${ }^{202}$ Information provided by the Wyoming State Engineer's Office (May 5, 2008) (on file with author). 
include popular trout fisheries with public access and streams with populations of Bonneville cutthroat trout, Colorado River cutthroat trout, and Yellowstone cutthroat trout.

Game and Fish recently succeeded in gaining State Board of Control approval for changing a water right historically used to support a fish hatchery to instream flow. ${ }^{203}$ The Department had decided to sell the hatchery. To maintain the hydrology associated with this non-consumptive right the Department wanted to convert the right to instream flow purposes. This is the first conversion of an existing water right to instream flow in Wyoming.

\section{Flow Protection on Federal Lands}

As mentioned, almost all instream flow appropriations under the state program occur on federal public lands. In addition, the State has established a water right in the name of the United States for the Clarks Fork of the Yellowstone River Wild and Scenic River designated by Congress in $1990 .{ }^{204}$ The State established instream flow water rights in the Shoshone and Big Horn national forests as part of a settlement agreement with the United States in the Big Horn Adjudication. ${ }^{205}$

\section{Restoring Stream Health}

While most attention to this point has focused on protecting unappropriated flows, there have also been efforts to improve and restore stream habitat and flows to enhance fisheries and other aquatic values and to improve their use for recreation and tourism. Thus the Bureau of Reclamation has operated several of its projects to provide flows beneficial to downstream fisheries. For example, Reclamation releases water from Kortes Dam on the North Platte in a manner

203 Telephone interview with Tom Annear, Instream Flow Supervisor, Wyoming Department of Game \& Fish (April 29, 2008).

204 Clarks Fork Wild \& Scenic River Designation Act of 1990, P.L. 101-547. As explained by the then State Engineer:

Negotiated language in this federal law authorized the Secretary of Agriculture to apply, through the procedural requirements of State law, quantify and secure a water right for the protection of the wild and scenic value of this particular river. Congress specified these values as beneficial uses for the purpose of allowing Wyoming's procedural laws for instream flow to be used for the appropriation and adjudication of the river flows needed to meet the purposes of the federal designation.

Fassett, Wyoming's Instream Flow Law, Instream Flow Protection in the West (rev'd ed. 1993), supra note 2, at 21-3.

205 Personal communication, Jeff Fassett, National Director of Water Resources, HDR Engineering, Inc. (June 16, 2008). 
that supports a high quality tailwater trout fishery. ${ }^{206}$ Similarly, releases from Fontanelle Dam support a cold-water fishery on the Green River.

Trout Unlimited ("TU”) has begun promoting partnerships with private and public entities in places like the Gros Vente River near Jackson, on the Little Laramie River, and in the Smiths Fork and Thomas Fork of the Bear River in Wyoming, Utah, and Idaho. ${ }^{207} \mathrm{TU}$ has been working with the Wyoming legislature to develop a bill that would enable leasing of water rights for instream flow purposes by entities other than the State.

\section{Summary}

By law, Wyoming's approach to instream flow protection focuses solely on fisheries; by policy, it is largely concerned with popular game fish but, more recently, has also emphasized native cutthroat trout. The state has concentrated on streams on public lands, especially in the higher elevation national forests. There is growing interest in restoration of streams, a process that is likely to bring increased interest in acquiring water or water rights to help restore flows. State funding for such acquisitions would substantially facilitate such efforts as would enabling holders of water rights to change their use to environmental flows.

\section{PART III-SOME ObSERVATIONS}

1. The legitimacy of environmental flow protection has gained increased policy and legal recognition in the Rocky Mountain states since the 1970s, but there remains a reluctance to regard this use of water as equivalent in importance to consumptive water uses.

Interest in environmental uses of water has led to affirmative legislative action in most Rocky Mountain states and judicial or administrative action in others. We have moved beyond questions such as whether environmental uses can be regarded as a beneficial use of water and whether an instream flow appropriation requires a physical structure to control and divert water. Thus it is now possible to protect water for environmental uses under state law in some manner in all of the states. The extent to which water has in fact been committed to environmental uses varies widely among the states, however, reflecting in part the relative abundance of water and in part the degree of political support.

${ }^{206}$ Lawrence J. MacDonnell, Managing Reclamation Facilities for Ecosystem Benefits, 67 U. Colo. L. Rev. 197, 220 (1996).

${ }^{207}$ Personal communication, Scott Yates, Wyoming Water Project Director, Trout Unlimited (April 18, 2008). 
That reservations among state legislators about environmental flow protection remain is evident from the many statutory limitations that still apply to establishing environmental flow rights and changing existing rights to environmental flows. For example, flows dedicated to environmental purposes in Idaho, Colorado, and Wyoming are expressly limited to the minimum amount. ${ }^{208}$ Idaho requires legislative review of instream appropriations made by the Water Resources Board. ${ }^{209}$ Montana law requires periodic reevaluation of instream flow reservations. ${ }^{210}$ Wyoming law only authorizes instream flows for fish. ${ }^{211}$ Colorado law subjects instream flow appropriations to existing but undecreed water uses. ${ }^{212}$ It authorizes a reduction in decreed flows at the determination of the Colorado Water Conservation Board. ${ }^{213}$ By regulation, it allows inundation of a protected stream segment and, under certain conditions, accepts injury to the right caused by other water right changes. ${ }^{214}$ Utah does not allow appropriations of new water rights for instream flow purposes. ${ }^{215}$ Several states allow only a governmental entity to appropriate water for instream flow; similarly, several restrict the ability to transfer an existing right to instream flow to the state. The list of limitations goes on.

It seems likely that this somewhat second-class status will diminish over time. There has been a clear trend toward recognizing the importance of maintaining water for environmental purposes. There is long-standing support for protection of stream segments with trout fisheries. There is growing interest in enjoying rivers for other recreational benefits as well. Such uses are non-consumptive. They protect important values without diminishing the amount of water potentially

${ }^{208}$ Current policy in these states is to treat this statutory term as justification for limiting appropriations to flow levels below that necessary to fully support fishery and other ecologic values. Idaho law, for example, states: "Approval of any such application must be based upon a finding that such appropriation of minimum stream flow: ... (d) is the minimum flow or lake level and not the ideal or most desirable flow or lake level; ....” IDAHo Code AnN. \$ 42-1503. A strong argument can be made, however, that the word "minimum" is simply another way of stating the fundamental principle of prior appropriation law that beneficial use always is limited to only that amount of water reasonably necessary to accomplish the purpose of the appropriation and no more. The quantity of water needed for an environmental flow water right depends on the purpose for which the right is established. See, for example the discussion by the Nebraska Supreme Court in In re Application A-16642, 463 N.W.2d 591, 610-11 (Neb. 1990).

${ }^{209}$ IDAHO CODE ANN. $\$ 42-1503$.

${ }^{210}$ Mont. Code Ann. $\$ 85-2-316$ (10).

211 See Reed Benson, "Adequate Progress," or Rivers Left Behind? Developments in Colorado \& Wyoming Instream Flow Laws Since 2000, 36 EnvT'L L. 1283 (2006).

212 Colo. Rev. Stat. $\$ 37-92-102$ (3)(b).

${ }^{213}$ Id. (4)(b).

${ }^{214} 2$ Colo. Code Reg. $\$ \$ 7,8(\mathrm{i})(3)$.

215 Utah Code Ann. \$73-3-30. 
available for meeting other human needs. ${ }^{216} \mathrm{~A}$ few states have affirmatively embraced the importance of environmental water, have established active state programs to identify high value places for protection, have committed at least some of the funding needed to provide the desired protections, and have worked positively with others who share this interest. These states recognize the need to protect and maintain the state's water-dependent heritage and the growing desire of many of their citizens to be able to enjoy the recreational and environmental benefits of healthy streams.

\section{Appropriations of water for environmental flow are heavily concentrated in high elevation, more remote streams that support a sport fishery.}

In part, the concentration of appropriations in relatively remote locations with viable fisheries simply reflects the reality that these are the only places with remaining unappropriated water in most states. Most people live in the lower elevation areas with lands suitable for development, including for agriculture. The streams in these areas have long since been fully appropriated to meet direct human uses. Urban water suppliers and some irrigation water suppliers have established storage facilities that divert water from high elevation streams, but the more remote these streams the less likely they are to have been regulated for human water uses. The focus on sports fisheries reflects both the importance of these fisheries to anglers and the role given to state wildlife agencies to identify places for protection of stream flows. To some degree, the Endangered Species Act has forced states to deal with flow requirements for other aquatic species. ${ }^{217}$ As attention turns to protection of important environmental values in lower elevation water sources, it becomes necessary to work with existing water users. States are beginning to develop more tools to work within these settings.

\section{Scientific understanding of environmental flows has burgeoned in} recent years, providing information needed to understand the essential role played by flows in maintaining healthy streams and helping to inform ways in which human uses of water can better be managed to enable maintenance of environmental values and functions.

An early goal of environmental flow protection was simply to prevent rivers and streams from becoming so dewatered as to lose their ability to support a

216 An ongoing concern is that such rights limit upstream development of water. Of course, all water rights do this because they establish a legally protected claim as available in priority to the flows of water upon which the purpose of the appropriation are based. The difference with environmental flow appropriations is that they are non-consumptive.

217 See Michael R. Moore et al., Water Allocation in the American West: Endangered Fish Versus Irrigated Agriculture, 36 NaT. Res. J. 319 (1996); Reed D. Benson, So Much Conflict, Yet so Much in Common: Considering the Similarities Between Western Water Law and the Endangered Species Act, 44 NAT. Res. J. 29 (2004). 
fishery. This goal was achieved so long as some flow remained in the stream. Now our better understanding of the role that stream flows play in supporting stream function calls for seeking to manage water so that flows more closely mimic the natural (pre-development) stream hydrograph. ${ }^{218}$ High flows are essential for maintaining channel form and for moving sediment. Peak flows that inundate floodplains recharge ground water, create important fish habitat, and support riparian vegetation communities. Base flows are essential to fish and much aquatic life. If flows become too low, water temperatures and concentrations of pollutants may increase beyond the tolerance level of aquatic species.

The Nature Conservancy has developed a framework for what is termed "ecologically sustainable water management." ${ }^{19}$ TNC describes this concept as follows:

Ecologically sustainable water management protects the ecological integrity of affected ecosystems while meeting intergenerational human needs for water and sustaining the full array of other products and services provided by natural freshwater ecosystems. Ecological integrity is protected when the compositional and structural diversity and natural functioning of affected ecosystems is maintained. ${ }^{220}$

The process provides participants with the information needed to make informed decisions about the tradeoffs between different levels and types of human water uses and the health of the river. A group of river scientists is developing a methodology they call the "ecological limits of hydrologic alteration."221 This approach relies on use of flow-ecology relationships developed by analysis of numerous rivers within a region. With a better understanding of possible outcomes, actions can be taken to establish the desired flow regime.

The Instream Flow Council has identified five riverine components it regards as essential for effective management of flows: hydrology, geomorphology, water

${ }^{218}$ A good starting point for reviewing the scientific literature emerging in this area is L. Poff et al., The Natural Flow Regime: A Paradigm for River Conservation and Restoration, 47 BIOSCIENCE 769 (1997). Also recommended are B. Richter et al., Ecologically Sustainable Water Management: Managing River Flows for Ecological Integrity, 13 Ecological Applications 206 (2003) and T. Annear et al., Instream Flows for Riverine Resource STEWARdShip (rev. ed. 2004).

${ }^{219}$ Richter, supra note 218, at 207.

${ }^{220} \mathrm{Id}$.

${ }^{221}$ A. Arthington et al., The Challenge of Providing Environmental Flow Rules to Sustain River Ecosystems, 16 Ecological Applications 1311 (2006). 
quality, biology, and connectivity. ${ }^{222}$ Methodologies for evaluation of these components are now being employed in river management across the U.S. and Canada, as well as in other countries. ${ }^{223}$ Much progress is being made in integrating improved scientific understanding of river function with other interests in river management and use.

Given the essential role played by flows, extractions of water for human uses could be timed in a manner that corresponds more closely to the hydrograph as well. That is, extractions could be distributed over the year to maintain the shape of the hydrograph, but at a lower level. Protecting the flow regime in this manner has been called an "upside down" instream flow water right because it reverses the traditional baseflow protection approach. ${ }^{224}$

\section{Stream restoration activities, sometimes motivated by legal requirements, are being supported through changes in state water law allowing changes of rights to instream flows, including temporary changes through leases or rentals.}

Streamflow restoration requires working with existing water uses. The challenges here are much greater than in making appropriations of unclaimed water. ${ }^{225}$ Water marketing to shift water from irrigation to urban uses has helped identify many of the challenges involved in making changes of water rights, and some states have modified their laws to better facilitate this process. In general, changing consumptive use rights to environmental flow purposes must go through the same procedures as water rights shifted to urban uses. ${ }^{226}$ These processes require affirmative demonstration of no injury to other water rights and may include review on other grounds, including public interest assertions.

Most changes of existing water rights to environmental flow simply involve the cessation of diversion of water and the elimination of the associated consumptive use. The primary potential injury issue is whether the new use results in an

222 Annear, supra note 218, at 98.

223 See, for example the case studies in A. Locke et al., InTEgrated ApproaChES To Riverine Resource Stewardship: Case Studies, Science, Law, People, and Policy (2008).

${ }^{224}$ N. Silk et al., Turning Instream Flow Water Rights Upside Down, 7 RIVERS 298 (2000). South Africa has changed its laws to place the fundamental needs of the river first, with human uses then obligated to adjust to become compatible with these needs. See Postel \& Richter, supra note 3, at 84-86.

${ }^{225}$ A useful discussion is provided in Malloch, supra note 2, at 30. Also see D. Garrick et al., Environmental Water Transactions: Lessons Learned \& Future Prospects, Proceedings of a workshop held September 2, 2007 in Brisbane, Australia as part of the 10th International Riversymposium and Environmental Flows Conference, March 2008, available online at http://cbwtp.org/jsp/cbwtp/ library/documents/Env\%20Water\%20Transactions\%20Proceedings.pdf (last visited Feb. 11, 2009).

${ }^{226}$ Malloch, supra note 2, at 26-27. 
injurious change in the timing of return flows so that stream conditions upon which downstream appropriators have depended are unacceptably altered. ${ }^{227}$ Moreover, the matter of historical consumptive use-usually the most contentious matter in a change of water right proceeding - is irrelevant unless the applicant intends to legally protect that amount of water downstream beyond the historical point of return flows. 228

In short, in many instances, it may be sufficient to demonstrate merely the historical pattern of diversions to establish the extent of the changed instream flow right. If the party making the change intends to protect the quantity of water historically consumed further downstream, then it will be necessary to determine the quantity and timing of this amount of water. It will also be necessary to develop a means of monitoring and protecting that water as it passes by downstream headgates.

Where an option, water rights holders have shown considerably more interest in leasing or loaning their rights or part of their rights for environmental flows than in selling them. ${ }^{229}$ In addition to specifically providing for leasing of water rights for environmental flows, several states have developed mechanisms to facilitate such transactions, including Idaho's water banks and New Mexico's Strategic Water Reserve. In this way, water right holders can avoid the use it or lose it rule that forces them to divert water even though they may not want to. 230 They retain the option to revive their use if they choose. In the meantime, the water stays instream for the benefits it can provide in that use.

The continuing reluctance in most states to allow owners of water rights to change the use of the right to environmental flows is puzzling. Western states uniformly regard water rights as property rights. The water right holder has complied with state law and placed some amount of water to beneficial use. The right to continue the use of water, in priority, is protected. Water right holders are able to transfer ownership of the right and make changes to any other uses,

227 Another possible injury, at least in Colorado, is the loss of groundwater recharge upon which well pumpers have relied. City of Thornton v. Bijou Irrigation Co., 926 P.2d 1, 78-82 (Colo. 1996).

228 Sale of the consumptive use portion to a downstream user can potentially provide a mechanism to help finance the original acquisition. In this case, quantification of historic consumptive use makes sense. Colorado law now specifically allows for this. Colo. Rev. Stat. $\$ 37-92-102(3)$.

229 Malloch, supra note 2, at 20.

230 Authorizing legislation should stipulate that such temporary instream uses do not raise questions of abandonment or forfeiture. Thus, for example, Idaho provides specifically that water rights placed in the water supply bank are not subject to the state's five-year forfeiture statute. IDAHO Code Ann. \$ 42-1764 (2). Moreover, water right owners will be more inclined to temporarily cease use if the process provides that the measure of the right's historic consumptive use will not be affected in the manner Colorado has done. See supra note 73. 
subject to the no injury rule, except for streamflow enhancement. A change to environmental flows actually increases water in the stream, benefiting not only the in-channel environment but also the supply of water potentially available for other downstream appropriators. There is no clear explanation why holders of water rights should not be free to change the use to environmental purposes or why such changes should be limited to a state agency. ${ }^{231}$

\section{There are illustrations of improved cooperation between states and federal agencies as well as tribes so that mutual interests respecting environmental flows can be met, but more can and should be done.}

An historic area of contention between the United States and the states concerns the availability of water for uses on federal and tribal lands. In general, states determine uses of water within their boundaries. The primary exception is when a reservation of public lands for such things as national parks or Indian reservation is determined to have reserved an amount of appurtenant water necessary to fulfill the purposes of the reservation. ${ }^{232}$ Such rights are regarded as existing independent of the normal state procedures for water appropriation. Beyond such reserved rights, federal land agencies and tribes must obtain rights to use water under state law.

In general, implied reserved rights that include instream flows have been found to exist for Indian reservations established under treaties that recognize fishing as an important purpose for which the reservation was established, ${ }^{233}$ for national parks because of their explicit preservation purposes, ${ }^{234}$ and for a few other such reservations. By statute, congressionally-designated Wild and Scenic Rivers are regarded as having reserved water rights. ${ }^{235}$ Implied reserved rights for instream flows have not been recognized for national forests. ${ }^{236}$ By terms of the National Wildlife Refuge System Improvement Act of 1997, the U.S. Fish and Wildlife Service does not seek reserved water rights for national wildlife refuges. ${ }^{237}$ In general, Bureau of Land Management lands are not reserved. Because the McCarran Amendment ${ }^{238}$ makes federal reserved rights subject to state general

${ }^{231}$ Most states have long been unwilling to allow users other than state agencies to appropriate water for environmental flows. The rationale has been that those with environmental interests would simply appropriate all unappropriated water. This view fails to consider that the appropriation has to go through a permitting or adjudication process.

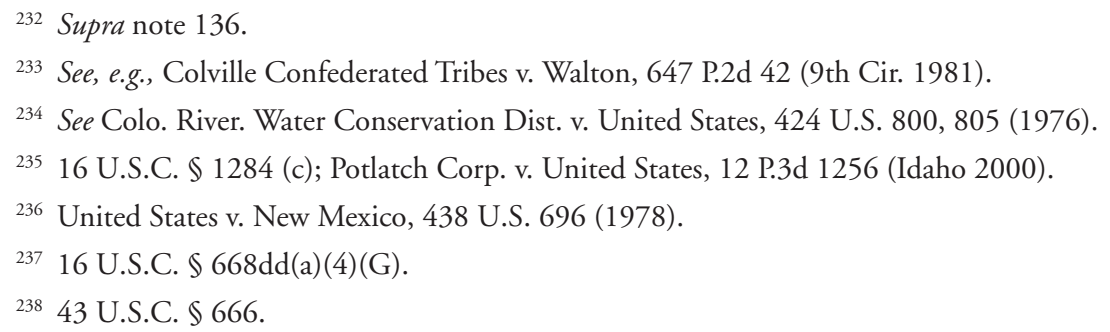


stream adjudications, quantification of such rights generally occurs in state proceedings. ${ }^{239}$

States generally seek to encourage resolution of federal interests in streamflow protection through use of state law. Montana has successfully used a special compact process to resolve federal reserved water rights claims. ${ }^{240}$ Several states invite federal agencies to submit their instream flow protection interests to the state agency process established under state law. ${ }^{241}$ Arizona and Nevada allow federal land agencies to directly appropriate water for environmental flow purposes. ${ }^{242}$ Several states have worked out agreements with the United States under which special legislation has been crafted to enable federal interests to be met under state law. ${ }^{243}$ Some states have put in place memoranda of understanding with federal land agencies calling for cooperative approaches to water matters. ${ }^{244}$

Nevertheless, state law governing protection of water for environmental purposes typically has a number of limitations that may not be consistent with federal and tribal land management objectives. ${ }^{245}$ In some instances, standard state law has been adapted to specially address federal concerns. Where these limitations cannot be bridged, federal agencies may feel unable to follow state procedures and will choose instead to rely on other means to achieve their objectives. An option that has been proposed is to authorize joint ownership of instream flow water rights between federal and state agencies. ${ }^{246}$

\section{There is an increasing number of participants working to protect and improve stream flows in the Rocky Mountain states.}

States jealously guard uses of water to benefit their interests. Once understood in the West to mean uses that generated income or supplied direct human needs,

${ }^{239}$ Colo. River Water Conservation Dist, 424 U.S. at 800. But see Reed D. Benson, Deflating the Deference Myth: National Interests Versus State Authority Under Federal Laws Affecting Water Use, 2006 UtAH L. Rev. 241 (2006).

240 Supra notes 133-39 and accompanying text.

241 See, e.g., supra note 77.

${ }^{242}$ Nevada has not acted on federal applications for instream flows for many years, however, Arizona stopped approving such applications during the Phelps-Dodge litigation, a process that now has moved into its second phase involving acceptable methods for quantifying instream flow claims. Personal communication from Randy Bramer, Office of General Counsel, U.S. Department of Agriculture (May 8, 2008).

243 See, e.g., supra note 81.

244 See, e.g., supra notes 79-82 and accompanying text.

245 Adele L. Amos, The Use of State Instream Flow Law for Federal Lands: Respecting State Control While Meeting Federal Purposes, 36 EnvTL. L. 1237 (2006).

${ }^{246}$ Lois Witte, Still No Water for the Woods, ALI-ABA Federal Lands Conference, October 19, 2001, available at http://www.stream.fs.fed.us/news/streamnt/apr02/apr_02_01.html (last visited Apr. 9, 2009). 
today state interests include helping to find ways to make water available for nonconsumptive, environmental purposes. Unlike with other beneficial uses of water, however, most states restrict the decision to appropriate water for environmental uses to exclusive state control.

Leaving aside the necessity for such restrictions, it is nevertheless true that those most interested in using water for environmental benefits are often involved in the processes under which this is possible. Thus fish biologists working for state wildlife agencies have been central to state efforts to protect stream flows. ${ }^{247}$ Occasionally, state parks and recreation departments encourage protection of flows for recreation if that is an allowable instream flow use. Even water quality agencies may weigh in because of the importance of flow for maintenance of water quality, again if protection of water quality is an allowable instream flow use. In addition, federal land management agencies have been actively involved in efforts to protect flows and lake levels within their lands. ${ }^{248}$

Nonprofits with a wildlife or biodiversity interest often are active participants. The Nature Conservancy has for many years been a leader in water-based biodiversity protection as a complement to its traditional land-based programs. ${ }^{249}$ Trout Unlimited's Western Water Project, with offices in many of the Rocky Mountain states, actively promotes flow protection and restoration for fish and other aquatic benefits. ${ }^{250}$ Modeled somewhat along the lines of land trusts, water trusts have been established in several western states with the objective of acquiring water or water rights for instream flow purposes. ${ }^{251}$ Individual watershed groups have developed in many Rocky Mountain states, some with an interest in streamflow protection and restoration. ${ }^{252}$ Cities also are increasingly interested in protecting and enhancing flows on streams that pass through their boundaries. ${ }^{253}$ In addition, there are riparian landowners-sometimes ranchers-

247 The Instream Flow Council is a non-profit organization with membership from virtually all state wildlife agencies as well as their counterparts from the Canadian provinces. See www. instreamflowcouncil.org (last visited April 6, 2009).

${ }^{248}$ A good overview of federal agency efforts through the mid 1990s is provided in Gillilan \& Brown, supra note 2 , at $177-223$.

${ }^{249}$ For an overview of TNC's program, see http://www.nature.org/initiatives/freshwater/ (last visited April 6, 2009).

${ }^{250}$ For an introduction to this program, see http://www.tu.org/site/c.kkLRJ7MSKtH/b. 3022975/ (last visited April 6, 2009).

251 There are water trusts in Montana (http://www.montanawatertrust.org/ (last visited April 6, 2009)) and Colorado (http://www.coloradowatertrust.org/ (last visited April 6, 2009)).

${ }^{252}$ For a listing of watershed groups by state see http://www.epa.gov/adopt/network.html (last visited Feb. 11, 2009).

${ }^{253}$ Reed D. Benson, Rivers to Live By: Can Western Water Law Help Communities Embrace Their Streams?, 27 J. LAND Res. \& EnVtL L. 1 (2007). 
with an interest in maintaining flows in streams that run through their property for fishery and aesthetic benefits. Moreover, rafting and kayaking enthusiasts are strong proponents of free-flowing rivers.

These entities and individuals bring people, expertise, and funding to the task of streamflow protection, much needed resources to supplement what is available through state and federal agencies. Obviously their participation is affected by the degree to which state law and processes enable them to accomplish their objectives. Precluding entities other than a state agency from acquiring and holding a water right for environmental flow purposes reduces their interest in putting in the time and expending the funds needed to make such acquisitions and go through the change of right process. Putting restrictions on the purposes for which environmental flows may be protected has the effect of keeping out those whose interests cannot be met. Limiting the tools available for entities to work with, such as by not authorizing leasing of water for environmental flows, limits their options and reduces their effectiveness.

That there are so many parties interested in streamflow protection underlines the growing importance placed on this use of water. Some states such as Montana have opened up their systems to enable participation in streamflow protection by all interested parties, in association with state efforts. ${ }^{254}$ Others such as Colorado have been welcoming in some respects and unwelcoming in others (such as restricting ownership of instream flow rights to a single state agency). ${ }^{255}$ The trend is clearly in the direction of inviting more participation, most importantly by allowing any party to either temporarily or permanently acquire existing water rights or water and changing their use to environmental flow.

\section{The environmental flow restoration toolbox is growing.}

Little has changed over the years in the manner in which states choose to set aside unused water for environmental purposes. Most states simply appropriate water for that purpose in the same manner as water users do for other water rights. States may also use their approval authority to condition approval of new appropriations on maintaining some minimum bypass flow to protect a stream reach.

There has been considerable development, however, in the legal tools by which existing water uses may be changed to provide enhanced stream flows. ${ }^{256}$ Some states have explicitly recognized that existing rights may be changed to

\footnotetext{
254 See supra notes $141-45$ and accompanying text.

255 Supra note 54.

${ }^{256}$ Malloch, supra note 2.
} 
environmental flow purposes. ${ }^{257}$ As mentioned, such changes must undergo state review to ensure no injury to other rights. Several states now have established procedures by which water rights may be leased for instream flow purposes. ${ }^{258}$ There may be limitations on who is authorized to hold these leases and on the number of years for which a right may be leased. There may also be limits on the purposes for which these leases may be made or even the watershed in which the transactions are allowed. But the door has been opened, and the results to date indicate considerable success with restoring stream flows using such approaches.

Purchasers and water right owners have shown considerable creativity in structuring transactions in ways that work for both interests. ${ }^{259}$ Some transfers, for example, are triggered only in drought years. Some transfers call for only a limited-term cessation of diversions, for example, at the time during the irrigation season when flows are regarded as most critical for such things as fish passage or to moderate water temperatures. There have been agreements that produced a desired reduction in diversions by paying for water use efficiency improvements. Other agreements have enabled a direct flow diverter to switch to groundwater pumping or even to shift to another, more abundant source of water.

8. Funding provided under the Columbia Basin Water Transactions Program has spurred innovative, voluntary efforts to restore stream flows needed by endangered fish in critical tributaries. Comparable programs should be established in other basins and states.

While flow restoration on larger rivers can often be achieved through reoperation of storage facilities managed by the Corps of Engineers or the Bureau of Reclamation, flow restoration in the smaller tributaries typically requires reducing existing diversions under individual water rights. Such work is difficult and time consuming and is only possible if there is a reliable source of funding. In just a few years, the Columbia Basin Water Transactions Program has spurred more than 150 transactions to produce critically needed flows for the benefit of endangered fish. ${ }^{260}$ The availability of this funding, generally tied to larger habitat restoration efforts, has enabled states in the Pacific Northwest and nonprofits to develop relationships with water right holders in key areas, to develop arrangements with some of these water right holders under which they are voluntarily willing to

257 See, e.g., supra note 185.

258 See, e.g., supra notes 141-45 and accompanying text.

259 Stories of results from transactions involving environmental flows are available on the Columbia River Basin Water Transactions web site available at http://www.cbwtp.org/jsp/cbwtp/ stories/stories.jsp (last visited Feb. 11, 2009).

${ }^{260}$ Information about this program is available at http://www.cbwtp.org/jsp/cbwtp/index.jsp (last visited Feb. 11, 2009). 
forego or reduce their diversions, and has encouraged states to develop legislative and administrative rules supporting these efforts.

New Mexico's Strategic Water Reserve represents a state-level commitment to providing funding and staff to acquire water and water rights to benefit federally listed species and, potentially, to help keep species from becoming listed. ${ }^{261}$ In this way, the state is helping their water users meet their legal responsibilities under the Endangered Species Act through voluntary rather than regulatory means. In 2008, the Colorado General Assembly authorized the Colorado Water Conservation Board to use funds from the state's species conservation trust fund to acquire water rights for instream flow purposes to benefit listed or candidate species or species of concern. ${ }^{262}$ Arizona has provided funding for stream restoration that includes the ability to acquire certain sources of water. ${ }^{263}$ These are important commitments of state funds to help support the task of streamflow restoration to meet the needs of species in jeopardy of extinction.

Acquisition of water rights is expensive. Any serious effort at flow restoration requires the financial resources necessary to obtain either ownership of existing rights or the ability to use some or all of these rights to enhance stream flows. It seems likely that some dedicated source of funding will be necessary. One option for consideration would be a fee on applications for changes of water rights, similar to a real estate transfer fee. ${ }^{264}$ Another possibility would be to establish a charge on all urban water uses, to be collected by the water supplier. It seems likely that states will find it difficult to appropriate general fund monies for this purpose. Thus, a dedicated source of funding will be necessary if progress is to be made.

9. Collaborative processes focused on restoring specific streams and stream segments are helping to build support for the importance of adequate stream flows to enhance and maintain desired healthy streams and fisheries.

An important trend in water management over the past 20 years has been the emergence of collaborative, multi-party processes by which acceptable changes in traditional water use patterns have been established, often to produce some desired environmental benefit. ${ }^{265}$ Sometimes these processes are driven by the need to

\footnotetext{
261 Supra note 173.

262 S.B. 09-168, Colo. Rev. Stat. \$24-33-11 (2)(II).

263 Supra note 27.
}

${ }^{264}$ An overview of real estate transfer fees, prepared by Trust for Public Lands, is available at http://www.tpl.org/tier3_cdl.cfm?content_item_id=1060\&folder_id=825 (last visited April 6, 2009).

265 See, e.g., Across the Great Divide: Explorations in Collaborative Conservation \& The American West, Philip Brick et al., eds. (2001). 
comply with federal law respecting endangered species protection, water quality, or hydropower licensing. The Upper Colorado River Fish Recovery Program is a prominent example. ${ }^{266}$ In other cases they emerge out of local interests in making watershed improvement (e.g., restoring flows in the Blackfoot River) or in responding to a perceived threat to the existing condition of the watershed (such as in Arizona's Verde River). Restoration of aspects of stream functionality, such as restoring sinuosity to a channelized stream segment or improving in-channel fish habitat, is often an integral objective. Still another means is a state-directed water basin planning process such as exists in Idaho. ${ }^{267}$ In many cases these processes provide a better understanding of the manner in which the traditional flow regime has been altered and the effects this alteration has had on aquatic and riparian values. Sometimes this understanding leads to a shared interest in taking steps to restore a flow regime that provides increased ecological benefits. Voluntary diversion reductions during drought in the Blackfoot River of Montana illustrate this point. ${ }^{268}$

There have been some striking outcomes. One is the surprising degree of flexibility that is often available within historical patterns of water use. Water uses develop incrementally over many years, based on patterns of growth and associated needs for water. Under a priority system these patterns tend to stay firmly in place unless there is some important reason for their reconsideration. Yet the base need is simply to assure that valuable water uses continue, not that they necessarily continue in the same manner as they always have. Once that premise is accepted, often many things become possible. Some uses may no longer be important or necessary. Thus New Mexico is retiring some irrigation water uses in the Pecos to improve stream flows. ${ }^{269}$ Water stored in Reclamation reservoirs in Idaho can be rented for release to meet downstream flow needs. ${ }^{270}$ Other uses may be able to be supplied or managed in different ways. A well can replace a surface water diversion to maintain stream flows. Dams can be operated in ways that are more river-friendly while still meeting their traditional purposes. ${ }^{271}$ The Alamo on the Bill Williams River in Arizona is an example. ${ }^{272}$ Perhaps most importantly, these changes have been accomplished voluntarily.

266 Information about this program is available at http://www.fws.gov/coloradoriverrecovery/ (last visited Feb. 11, 2009).

267 Supra note 103.

${ }^{268}$ Blackfoot Challenge, Better Communities Through Cooperation, http://www.blackfoot challenge.org/ (last visited Feb. 11, 2009).

269 See supra note 177 and accompanying text.

270 See supra note 110 and accompanying text.

271 For examples of how this is occurring see MacDonnell, supra note 206.

272 See supra notes 43-45 and accompanying text. 
10. Committing water to environmental purposes will be challenged by growing demands for consumptive uses of water associated with growing populations and by changes in water availability associated with climate change.

Dedicating water to environmental uses will not get easier in the years ahead. The Rocky Mountain West contains some of the nation's fastest growing states. ${ }^{273}$ Urban water demands are expanding as a result. Moreover, water demands associated with development of the region's important energy resources are growing as well. ${ }^{274}$ Set against this pattern of growing water demands is a growing body of research indicating that the region's hydrologic patterns as recorded over the past century and more are changing. ${ }^{275}$ The consensus is that for some critical sources of water supply such as the Colorado River basin the supply is likely to diminish. In other places, continued global warming is going to affect the region's dominant source of supply: runoff from the mountain snow pack. Increases in stream temperatures will place greater stress on fish and other temperaturesensitive aquatic life.

In this context the importance of protecting water for environmental purposes is likely to once again be debated. The discussion, however, is likely to be different from the one held 30 years ago. We are less likely to debate whether environmental water should be protected and more likely to focus on how and where water should be maintained for such purposes. Few today would suggest that protecting water for the environment is not important or has no value. Indeed, its value for these purposes is increasing as such water becomes increasingly scarce. We have learned a great deal about how water for the environment can be protected in a manner that is compatible with other interests. Environmental flows are non-consumptive. Their protection increases beneficial use of water without precluding other uses. We have made substantial progress over the past three decades in environmental flow protection, progress that has occurred while simultaneously meeting new water demands and without forcing an end to existing water uses. We can use the lessons we have gained from these efforts and apply them to the challenges of the future. 2006.

273 Western Governors Association, Water Needs and Strategies for a Sustainable Future, June

${ }^{274}$ Id. at 7. See also Western Resource Advocates, Water on the Rocks: Oil Shale Water Rights in Colorado (2009).

275 See, e.g., National Research Council, Colorado River Basin Water Management: Evaluating and Adjusting to Hydroclimatic Variability (2007). 


\section{PART IV- \\ Recommendations for Next Steps in the Rocky Mountain States}

While all the Rocky Mountain states now have in place at least some mechanism by which water may be committed to environmental uses, they have followed different approaches and have achieved different results. Offered here are suggestions for possible next steps for each of the states to consider.

\section{A. Arizona}

Arizona law accommodates protection of environmental water, but the state has no program of its own for this purpose. Understandably, water providers in the state are concerned primarily with how the state's limited supplies can be used to meet human demands. Yet it is evident there are many Arizona residents who value those special places in which stream flows and springs still support a rich natural environment. Such places have become even more valuable because of their scarcity. An important legislative action was to establish the Arizona Water Protection Fund in $1994 .{ }^{276}$ It is time for the state to consider next steps. One easy change would be to authorize use of this fund for acquisition of existing water rights in addition to CAP water and effluent. Simultaneously it would be useful for the legislature to clarify the rules applying to changes of water rights to environmental purposes. Any owner of an existing right should be permitted to make such a change, at least temporarily. Any interested party should be able to lease rights for environmental flow uses. Indeed, the legislature may want to direct one or more of the state's agencies to play an active role in identifying highvalue water-dependent places for protection or restoration. While the work of nonprofits and others respecting environmental water in Arizona has been quite remarkable, the needs and opportunities suggest a potentially important role for the state. In addition, now that questions about the legality of the state instream flow process are resolved the Department of Water Resources should move ahead with the many pending applications. Finally, with limited acknowledgement now in place under Arizona law that groundwater pumping can harm surface water rights, the State should provide a means by which any new groundwater pumping must offset its depletions to surface flows.

\section{B. Colorado}

Colorado has one of the region's most active instream flow protection programs. In recent years the state legislature has taken important steps to

276 ArIZ. Rev. Stat. \$S 45-2101 et seq. Funds under the program can be used to acquire water from the Central Arizona Project or effluent for environmental restoration purposes. For an overview of restoration projects in the state, many using funding from this source, see S. Megdal et al., Projects to Enhance Arizona's Environment: An Examination of their Functions, Water Requirements and Public Benefits, Arizona Water Resources Research Center, May 2006. 
enhance the program, such as by clarifying the ability of the Colorado Water Conservation Board to lease existing water rights, change their use to instream flows, and sell the right to use the consumption use portion to a downstream user, as well as by providing funding for such acquisitions. To this point, the State has been unwilling to allow entities other than the CWCB to hold rights acquired for instream flow. While some parties have been willing to donate or sell rights to the CWCB, it is likely that allowing any owner of a water right to either temporarily or permanently change use of the right to instream flows would encourage more to do so. The legislature should remove this unnecessary limitation. In addition, the state should consider using the Basin Roundtable process to identify and evaluate remaining opportunities for streamflow protection and restoration. ${ }^{277}$

\section{Idaho}

Idaho has taken significant actions to protect flows for environmental benefits over the years. Except under its comprehensive water basin planning program, however, it has tended to be more reactive than proactive in recent years. The legislature keeps an unusually tight leash over environmental flow decisions and, as in Colorado and Wyoming, only a single state agency is authorized to hold water rights for minimum flows. Temporary transfers of existing rights are permitted only to provide flows to a segment with an established minimum flow right. The legislative creation of a special water bank for the Lemhi River with simplified procedures was a creative action to help restore flows in that particular watershed. The Lemhi model should be expanded to other watersheds in which there is an interest in restoring flows. The State has opposed participation by nonstate partners in the Columbia Basin Water Transactions Program in Idaho. ${ }^{278}$ Given the challenges of successfully negotiating environmental flow water transactions, it would seem that other qualified partners would bring valuable and needed assistance to these efforts. Idaho may wish to continue its practice of only allowing appropriations for state-determined minimum flow segments, but it should consider enabling any party to change the use of an existing water right to environmental flow uses, either temporarily or permanently. There is no good reason to preclude an appropriator from voluntarily choosing to restore stream flows rather than continuing to divert that water. Finally, Idaho should place renewed attention on its water basin planning process including determination of river segments deserving of protected status.

277 Information about the roundtables is available at http://ibcc.state.co.us/ (last visited Feb. 12, 2009).

278 Telephone interview, Kimberly Goodman, Idaho State Director, Trout Unlimited (April $18,2008)$. 


\section{Montana}

Montana appears to have embraced the value of environmental flows more than any other state in the region. It has reserved significant amounts of water for instream flows, worked cooperatively with federal land agencies and tribes to resolve reserved rights matters, and encouraged all interested parties to participate in streamflow restoration through purchase or lease of existing water rights. The State is working to address problems created by increasing groundwater pumping in areas closed to new surface water appropriations. While funding for environmental flow water transactions is available in the western part of the State through the Columbia Basin Water Transactions Program, there are no funds available for transactions in the Missouri Basin. The State may wish to consider creating such a fund. In addition, the State should consider allowing any water right holder to permanently change the right to environmental flows.

\section{E. Nevada}

Nevada's efforts to protect environmental water have focused primarily on its wildlife management areas. Otherwise, the State itself has not played a very active role. Like Arizona, its laws potentially accommodate environmental flow protection and allow changes of water rights to environmental flows. In practice, however, the State Engineer has been reluctant to issue water rights for environmental flow purposes. Recent adoption of a law authorizing temporary conversion of agricultural rights to instream flows represents an important affirmative expression of support for such action. But there is no state program focused on identifying places of special value outside the wildlife management areas that require protection or restoration of water. There is no state funding that would facilitate efforts to make such changes. These are actions that the State might wish to consider to ensure the long-term protection of its unique water-dependent environments.

\section{F. New Mexico}

New Mexico took an important step toward protection of environmental flows with creation of its Strategic Water Reserve. Successful use of the Reserve in the Pecos demonstrates its utility. This mechanism is limited, however, to use for addressing the needs of endangered species. And it is only usable by the Interstate Stream Commission. Yet there are other places in the State where there is interest in restoring stream flows, places not involving endangered species but with other important values. An expansion of the use of the Strategic Water Reserve to such places would be a logical next step. Additionally, New Mexico should consider explicitly allowing owners of water rights to change the use of the right, either temporarily or permanently, to environmental flows. One way to accomplish this objective without legislative action would be for the State Engineer to develop rules providing for such changes, using New Mexico's change of water right 
statute and the Opinion of the Attorney General as authority. ${ }^{279}$ Such clarifying rules might be helpful to entities such as the City of Santa Fe who want to acquire water rights for environmental flows but are uncertain about applicable rules and procedures. ${ }^{280}$ The State's new River Ecosystem Restoration Initiative, under which funds are available under a competitive grant program, could potentially provide money for acquisition of rights if it is continued and if the rules about such acquisitions and transfers are made clearer.

\section{G. Utah}

Despite legislative recognition of instream flows in 1986, the State has done little since then to pursue acquisition of water rights for this purpose. The legislature's recent decision to enable fishing groups to temporarily change water rights to enhance flows for native trout is a step in the direction of encouraging participation by others in this work. ${ }^{281}$ Assuming this new authority is successful in enabling such groups to find water for fish, the State might want to consider broadening this program by removing some of the restrictions and allowing it to operate statewide. The State should also consider providing funding to its state agencies to enable them to acquire water and water rights as appropriate for enhancement of flows.

\section{H. Wyoming}

Wyoming has worked systematically to identify stream segments with high value fisheries and to protect flows in these segments. Very little appears to have been done, however, to acquire existing water rights for flow enhancement. State law authorizes the State to acquire rights for this purpose, but apparently no funding has been authorized for this purpose. Moreover, the ability to acquire rights for instream flows is limited to the State. The Town of Pinedale sought to use its water rights in a storage reservoir to enhance flows in Pine Creek, but the State Engineer determined that only the State could hold and use a water right for this purpose. ${ }^{282}$ The State should consider authorizing at least temporary use of an existing water right for instream flows by parties other than the State. Moreover, it should consider providing funding to state agencies to enable the purchase or lease of existing water rights for instream flow purposes, perhaps in connection with a state program for river restoration.

279 Personal communication, Beth Bardwell, Acting Senior Program Officer, World Wildlife Fund, Las Cruces, NM, June 17, 2008.

${ }^{280}$ Personal communication, Kyle Harwood, Harwood Consulting, Santa Fe, NM, June 6, 2008.

281 Supra note 187.

${ }^{282}$ C. Urbigkit, Town Seeks Exemption to State Water Law, Sublette Examiner, October 26, 2006. 


\section{Part V-Concluding Thoughts}

Dedication of water to environmental purposes is now well established as a potential use in all the Rocky Mountain states. The extent to which water has in fact been committed to such purposes varies widely among the states, however, dependent in good part on the availability of unappropriated water in the state. Thus the more arid states of Arizona, New Mexico, Nevada, and Utah have committed the least water to these uses. In all states, with the possible exception of Montana, there remains a strong belief that protection of water for environmental purposes constrains future development options that are regarded as more valuable. The result is that decisions about protecting environmental flows are based more on politics than science, or traditional views allowing individuals to determine beneficial uses of water.

The desire for strong state control of decisions allocating water to environmental flows suggests that state-run processes are more likely to succeed at working out the trade-offs that are clearly part of these decisions. Additionally, state programs have the obvious advantage of having staff specifically focused on this task. Thus this survey suggests protection of environmental flows is more likely to be successful when such a program exists-especially if the program is given the staff and resources necessary to its implementation. These programs should serve as the conduit through which those most directly interested in streamflow protection can work to achieve their objectives. As an inducement to engaging federal and tribal land management agencies in these processes, states should allow joint ownership of environmental flow rights on federal and tribal lands.

The challenge of restoring depleted stream flows is more complex. Again the existence of a state program that includes this mission seems beneficial, primarily because of the need for multiple sources of effort that can bring resources from different places. ${ }^{283}$ In this area, however, the work involves existing water rights rather than unappropriated water. Here the holders of water rights themselves should be allowed to change these rights to environmental flows while still retaining ownership of the right, including enabling a flexible mix of temporary arrangements. Any interested party should be allowed to lease water rights for environmental flows. Several states are moving in this direction, but tentatively, and with continuing unnecessary restrictions. Provision should be made for allowing short-term (less than one year) commitments to environmental flows

283 In fact, none of the states has made flow restoration a clear state objective. By authorizing state agencies to enter into leases for this purpose, as in Colorado and Montana, the state is implicitly acknowledging the value of flow restoration efforts. New Mexico's Strategic Water Reserve also acknowledges the need for the state to engage in flow restoration, at least for purposes of compliance with the Endangered Species Act. It would be preferable for states to make stream restoration (including flow restoration) an explicit part of a state agency's mission. 
with expedited procedures for consideration of injury, similar to the Colorado loan program. ${ }^{284}$ Non-permanent commitments to environmental flows should be protected to toll considerations of abandonment or forfeiture and to maintain the historical consumptive use associated with the right. Allowing downstream use of this portion of water both enables administration of the right and makes possible sale of the water to help finance acquisition of the right.

The traditional reservations about allocating unappropriated water to environmental uses seem less persuasive in the restoration context. Here we are considering uses of water that has already been applied to beneficial use, vesting the holder with a property right to continue that use. Determination of future use of that water has been given to the right holder, subject to the traditional no injury limitation, except for the purpose of environmental flows. Moreover, the quantities of water are typically modest-defined according to the already permitted diversion of water. This water has already been tied to the point of diversion of the original right so the change would have no upstream effects. The result of the change is to diminish or eliminate the historic beneficial consumptive use so that this amount of water would now be able to flow downstream. The only real concern to downstream water rights would be any changes in the timing of flows because of elimination of diversions and historical return flows. The physical amount of water in the stream would actually increase. Any such adverse effects on downstream water users would be addressed in the change-of-use proceeding.

Funding for stream restoration, including acquisition of water rights, remains a formidable obstacle to progress. The Columbia River Water Transactions Program demonstrates the importance and value of having such a reliable source of funding. ${ }^{285}$ While several Rocky Mountain states have established sources of funding for such work, the need far exceeds existing resources. Two potential sources of such funding are a fee on changes of water rights or a charge assessed on urban and industrial water uses.

Direct human needs for the Rocky Mountain West's limited water resources remain the primary concern of policy makers. Yet public demands for healthy streams have become increasingly important in water decision-making. These are not irreconcilable objectives. Growing interest in environmental flows represents an evolving sense of how we should manage our rivers, streams, and aquifers. Maintenance of a more naturalized flow regime represents a considerable change in the traditional way we have approached water management. In many places there simply is not the flexibility in the system to allow us to achieve this objective. Yet, as our actions over the last 30 years reflect, we can do far more than we had

\footnotetext{
284 Supra note 72.

285 Supra note 106.
} 
been doing. We can do this without impairing our ability to satisfy our other direct human requirements for water. We have made significant and measurable progress, but there are many opportunities to do more. 